\title{
Identifying, Categorising and Exploring 'Ælfrician' Vocabulary Using the Dictionary of Old English, A Thesaurus of Old English and Evoke
}

\author{
Amos van Baalen | ORCID: 0000-0001-5970-043X \\ Leiden University Centre for Linguistics, Leiden University, \\ Leiden, Niederlande \\ amwvb@outlook.com
}

\begin{abstract}
Ælfric of Eynsham $\left(c .955^{\times 957-c .1010}\right)$ is one of the most prominent authors of the Anglo-Saxon period. Despite this fact, there has not yet been an exhaustive study into his typical vocabulary. This article employs the Dictionary of Old English and prior scholarship in order to collect and categorise the lexis that is characteristic for his works. This vocabulary is then analysed using the web application Evoke together with A Thesaurus of Old English, which provides insights into the semantic domains that predominate in Ælfric's vocabulary, as well as the degrees of ambiguity, synonymy and specificity of his typical lexis.
\end{abstract}

Keywords

Ælfric of Eynsham - vocabulary - Old English - Dictionary of Old English - A Thesaurus of Old English - Evoke

1

\section{Introduction}

Ælfric of Eynsham (c.955×957-c.1010) is arguably the best-known and most prolific writer of Anglo-Saxon England (Hill, 20o9: 36-37). Ælfric's significance for the history of the English language stretches beyond the Norman Conquest, since his works were copied until the early thirteenth century (Treharne, 2009: 400). Aside from his own works being copied in the centuries after the Conquest, Ælfric's influence on new compositions made in this period 
is also occasionally cited. For instance, one study by Elaine Treharne, which focuses on the twelfth-century English translation of Ralph d'Escures' homily on the Assumption of the Virgin Mary, notes that "[m]uch of the vocabulary [of the text] is Ælfrician in nature, so that relatively rare words like 'wiðmeten,' 'bearneac[n]inde,', and 'earplættigen' appear to be based on a thorough knowledge of Ælfrician prose" (Treharne, 2006: 185, n. 26). The three lexemes that Treharne provides as examples of 'Ælfrician' vocabulary differ in some important aspects. According to the Dictionary of Old English (DOE), the adjective bearnea acniende 'big with child' and the verb éarplcett( $i$ )an 'to strike on the ear' are quite rare in the Dictionary of Old English Corpus (DOEC): bearnēacniende occurs only three times in the corpus, twice in the works of Ælfric and once in Ralph d'Escures' homily (DOE, s.v. bearn-ēacniende), while éarplcett(i)an occurs twice in the $D O E C$, once in the works of Ælfric and once in d'Escures' homily (DOE, s.v. éar-plcettan, éar-plcettian). ${ }^{2}$ By contrast, a search in the DOEC for all instances of the verb wiðmetan 'to compare' reveals that 20 out of its $5^{6}$ occurrences are found in the works of Ælfric, and that this lemma is found in more than 20 distinct texts in the corpus.

The discrepancies between these lemmata, which have all been termed ‘Ælfrician' by Treharne, raise some important questions. First of all, if a lemma is found only in the works of Ælfric and one other text, but occurs rarely, can this lemma really be considered characteristic of Ælfric's lexis? Similarly, can a lexical item that is found in more than twenty distinct texts also be labelled as ‘Ælfrician'? Indeed, how can 'Ælfrician' lexemes such as bearnēacniende and wiðmetan be compared to each other? Is it possible to make a classification system that can differentiate between lexemes which are either more or less typical for Ælfric's vocabulary?

In order to answer these questions, a general overview of Ælfric's characteristic vocabulary would be helpful. To my knowledge, such a large-scale study has not yet appeared, although there are some smaller studies in which some tendencies in his lexis are highlighted (e.g., Jost, 1927; 1950; Pope, 1967: 99-103; Ono, 1988). In order to fill this lacuna, this article demonstrates how this prior scholarship and the $D O E$ can be used to collect and categorise vocabulary that

1 The lack of the medial $<\mathrm{n}>$ in Treharne's quotation is most likely a typo, since the word appears as "bearneacninde" in Rubie D.-N. Warner's edition of the manuscript, London, British Library, Cotton Vespasian D. xiv (Warner, 1917: 138, l. 6), and also appears as such on fol. $156 \mathrm{r}$ of the manuscript: see http://www.bl.uk/manuscripts/Viewer.aspx? ref=cotton_ms_vespasian_d_xiv_fi56r.

2 The related verb ge.ēarplaettan has one occurrence in the corpus, in the works of Ælfric (DOE, s.v. ge.ēar-plcettan). 
has been identified as being characteristic of Ælfric's writings. Next, the article shows how the web application Evoke (Stolk, 2018) may be used to further explore this Ælfrician vocabulary.

Section 2 will address the collection and the categorisation of the Ælfrician lemmata, as well as discuss a number of issues relating to the use of the $D O E$ for studies of this type. Subsequently, section 3 will focus on using $A$ Thesaurus of Old English (TOE) and Evoke to explore Ælfrician lexis. I will discuss the process of tagging the Ælfrician vocabulary in Evoke and the issues that were encountered during this process, the tendencies which characterise Ælfric's typical lexis, and a number of categories in TOE in which Ælfric's vocabulary is over- and underrepresented. In the conclusion, some further possible avenues of research into Ælfric's vocabulary will be pointed out. A full overview of the Ælfrician vocabulary established on the basis of the $D O E$ and prior scholarship is provided in Appendices A and B.

The label 'Ælfrician' is not one which was used in Ælfric's own day. Rather, it is a term that will be employed in this article to refer to vocabulary which prior scholarship and the $D O E$ have identified as being restricted or predominantly found in Ælfric's works, or lexical items that were preferred by him over synonymous lexemes. When the term 'Ælfrician' is used to refer to vocabulary that is primarily found in or restricted to the works of Ælfric, it is quite likely that his contemporaries, whose works have simply not come down to us, may have used the same words. Since the corpus of Old English texts is incomplete and Ælfric's works are overrepresented in this corpus, especially so in particular text genres, such as grammars, the label 'Ælfrician' is simply used in relation to the texts that we have left (see also section 2.4).

\subsection{Sources: DOE and Prior Small-Scale Studies}

The $D O E$ is the most important source for any study dealing with Old English lexis. In addition to listing senses of lemmata, the $D O E$ also provides citations for these senses, and occasionally provides information on the usage of particular lemmata, for instance, when they are found frequently in the works of Ælfric. For this reason, the $D O E$ was consulted first in order to find lemmata which have been labelled by this dictionary as Ælfrician. These words can be identified in the $D O E$ by the information that the entries provide following the number of occurrences of a lemma. For instance, the entry for the lemma antimber 'material, substance' mentions the following about the occurrence of the lexeme in the DOEC: "ca. 45 occ. (freq. in Ælfric)" (DOE, s.v. an-timber). The 
$D O E$ uses a number of different labels for Ælfrician vocabulary. For instance, the lemma anmōdlīce 'resolutely' has six occurrences "in Ælfric", meaning that it is wholly restricted to the works of Ælfric (DOE, s.v. an-mōdlice). Two other labels which are often encountered are "mainly in Ælfric" (see, e.g., DOE, s.v. $\bar{a}$ fnung) and "freq. in Ælfric" (see, e.g., DOE, s.v. ed-wist), which are applied to lemmata that also occur outside of Ælfric's works. ${ }^{3}$ Searching for 'ælfric' in the "Occurrence" field identifies all of the lemmata which have been labelled as Ælfrician in the DOE. In addition, searches were performed for the short titles of Ælfrician works, such as ‘ÆCHom,' ‘ÆLs', and ‘ÆGram' in the same field, since lexemes that primarily or exclusively occur in these works can also be seen as part of Ælfric's vocabulary as a whole. ${ }^{4}$ These lexemes employ labels similar to those mentioned above, such as "in ÆGram" (see, e.g., DOE, s.v. äxiendlic) or "mainly in ÆGram" (see, e.g., DOE, s.v. dēedlic).

The current edition of the $D O E$ only goes up to the letter I. In order to complement the data from the $D O E$ with information about lemmata beyond the letter I, a literature review was also conducted, which has aimed to include as many sources as possible that mention lexemes seen as characteristic for Ælfric. ${ }^{5}$ Through a number of small-scale studies, previous scholarship has established that Ælfric exhibits a consistent lexical usage which is characteristic of his works. The first to note Ælfric's preferred usage of certain lexical items over synonymous lemmata was Dietrich (1855: 544-545, fn. 140). Since Dietrich's article, there have been many studies which have mentioned similar preferences, as well as the restriction of particular lemmata to the works of Ælfric; prominent studies include those by Jost (1927; 1950), Pope (1967: 99-103), Godden (1980), and Ono (1988). ${ }^{6}$ Another important facet of research into Ælfric's vocabulary relates to his usage of the 'Winchester vocabulary' a particular lexical usage associated with the school of Ælfric's teacher Æthelwold - of which "Ælfric is considered [the] most prominent and most consistent proponent” (Gretsch, 2009: 125). ${ }^{7}$

3 It is not immediately clear what the difference is between these labels; see section 2.2.

4 I also searched for the abbreviations of the biblical books that were translated, either wholly or in part, by Ælfric, which resulted in four lemmata that primarily occur in the prose translation of the book of Genesis (search term: 'gen'; I also searched for 'num', 'josh' and 'judg'). In order to identify which parts of Genesis (and the other books of the Heptateuch) were translated by Ælfric, I relied on Kleist (2019: 132-135) and the citations given there.

5 Due to the scope of this endeavour, these claims were not verified in the DOEC. The grammatical terms that occur in Ælfric's Grammar form an exception to this rule, since their relevancy has been determined by checking their occurrences in the DOEC. See section 2.2 below.

6 For a summary of the earliest research into Ælfric's vocabulary, see Ono (1988: 75-84).

7 Cf. Gretsch (2001: 47) and Hofstetter (1987: 58). For an analysis of Ælfric's usage of the Winchester vocabulary, see Hofstetter (1987: 38-66) and see also Gretsch (2001: 47-54) for possible additions to the vocabulary items mentioned by Hofstetter. 
An attempt has been made to include as many studies as seemed relevant, but sources that have been shown to be problematic in later literature have been avoided. ${ }^{8}$ In consulting the sources, the focus was solely on Ælfric's lexical usage, which includes lexemes that are restricted to his works, preferred lexemes, and the use of meanings which are particular to Ælfric. In other words, data such as Ælfric's preferential use of the verb bedēlan with an object in the genitive, rather than the dative (Jost, 1950: 122), have not been included. Features of Ælfric's vocabulary that either I or the relevant source deem of questionable relevance, such as Ælfric's preference of $s w \bar{a} s w \bar{a}$ over a single $s w \bar{a}$ (Pope, 1967: 102-103), have also not been cited. It should be stressed that there is a vast amount of literature on the peculiarities and tendencies in the vocabulary of Ælfric of Eynsham. Although my study is not exhaustive, I believe that I have gathered the most important sources on Ælfric's vocabulary.

\subsection{Categorisation}

Although the $D O E$ employs a number of different labels for Ælfrician vocabulary, it is not immediately clear how labels such as "mainly in Ælfric" and "freq. in Ælfric" differ from each other, nor how these labels differ from other, less frequently used labels, such as "disproportionately freq. in Ælfric" (see, e.g., $D O E$, s.v. cyre). For this reason, it was deemed necessary to create a categorisation which could be used to create a distinction between the lexemes which are more strongly associated with Ælfric and the lexemes which may be less characteristic of his works. In this categorisation system, an Ælfrician lemma is assigned to one of four categories, A-D, based on the number of non-Ælfrician texts in which the lemma occurs. The reasoning behind this system is that a higher number of non-Ælfrician texts implies that a lemma is less exclusive to the works of Ælfric and, for this reason, may be less characteristic of his lexis. The four categories are given below:

- Category A contains lexemes which exclusively occur in the works of Ælfric, e.g., bedūfan 'to sink' (DOE, s.v. be-dūfan).

- Category B contains lexemes which occur in the works of Ælfric and one other text, e.g., hremman 'to hinder' (DOE, s.v. hremman).

- Category C contains lexemes which occur in the works of Ælfric and between two and four other texts, e.g., flösclicnes 'incarnate condition; incarnation (of Christ)' (DOE, s.v. flēesclicnes).

- Category D contains lexemes which are frequently found in the works of Ælfric and occur in five or more other texts, e.g., cepelboren 'of noble birth' (DOE, s.v. cepel-boren).

8 For a brief overview of these studies and the criticism that they have received, see Ono

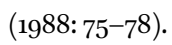


In order to make a more detailed distinction between more and less characteristically Ælfrician vocabulary, categories $\mathrm{A}-\mathrm{C}$ each have two subcategories, which relate to a lemma's total number of occurrences in the $D O E C:{ }^{9}$

- Category 1 contains lexemes which occur five or more times in the DOEC.

- Category 2 contains lexemes which occur fewer than five times in the DOEC. ${ }^{10}$

If a lemma is rare even in the works of Ælfric, it may be argued that this lemma is less characteristic of his vocabulary, and of limited relevance for the identification of typically Ælfrician lexis. The four categories listed above, in combination with the subcategories used for categories $\mathrm{A}-\mathrm{C}$, facilitate the use of a convenient shorthand. A lemma such as dydrung 'delusion' may be referred to as a 'B1 lemma', which indicates that it occurs in the works of Ælfric and only one other text, and has at least five occurrences in total in the DOEC (DOE, s.v. dydrung).

In order to categorise the lemmata retrieved from the $D O E$ using the categorisation given above, it is necessary to be able to identify Ælfrician and non-Ælfrician texts. The works of Ælfric are indicated as such in the $D O E$ by either their Cameron number (B1) or otherwise the prefix 'Æ' (e.g., 'ÆLS', which refers to Ælfric's Lives of Saints). ${ }^{11}$ In addition, I have relied on the work of Aaron J. Kleist in order to determine which parts of the Heptateuch were translated by Ælfric, and to identify any other texts which are believed to have been written by Ælfric, but which have not been categorised as such by the $D O E$ (Kleist, 2019: 66-206)..$^{2}$ Counting the number of non-Ælfrician texts in which a lemma occurs was carried out based on the texts cited in the entry of a lemma in the DOE. Whenever these texts numbered fewer than five and not all occurrences of the lemma were given in the entry, I also consulted the $D O E C$ in order to check for any other texts, whenever this was reasonably possible. Determining whether similar texts, such as manuscript variants, should be considered different texts is always a complicated task. Whenever possible, the $D O E$ entries have been followed. For instance, if different texts are given

9 This information is provided in every $D O E$ entry.

10 This subcategorisation is not possible for category $\mathrm{D}$, since the lemmata in this category occur in at least five non-Ælfrician texts, which means that they have at least five occurrences (not counting their occurrences in the works of Ælfric).

11 Notable exceptions are 'ÆColl' (the gloss to Ælfric's Colloquy), and 'ÆGl 1', 'ÆGl 2' and 'ÆGl 3' (the additions to his Glossary) which were not written by Ælfric.

12 All of the categorised lemmata may be found in Appendix A (Ælfrician vocabulary found in the $D O E$ ) and Appendix B (Ælfrician vocabulary found in prior scholarship) at the end of this article. In the appendices, references to Kleist (2019) are provided in the appropriate footnotes whenever this is relevant, for instance, if the consideration of a text as Ælfrician has led directly to a particular categorisation of a lemma (e.g., as $\mathrm{C}_{1}$, rather than D); in other cases, references are not provided. 
in a single quote, these texts are usually counted as one single text. However, other texts have been counted separately despite their similarities; charters, for instance, may use similar formulas, but are nevertheless different texts. Composite homilies which make use of Ælfrician material presented a difficult case. Sometimes the Ælfrician text in the composite homily may be virtually identical to the edition of the Ælfrician base text in the DOEC; at other times, the composite homily may differ from the base text in terms of word order, omissions, etc. In order to be consistent, all composite homilies containing Ælfrician material have been counted as non-Ælfrician texts.

Works that have been identified by the $D O E$ as having been written by the same author have been counted as a single text, such as the combined works of Wulfstan. These texts are arguably all examples of the same, idiosyncratic lexical usage of their author. Other texts that have been taken to constitute a single unit include the various versions of the glosses to Aldhelm's De laude virginitatis, such as 'AldV 1 (Goossens) C31.1' and 'AldV 13.1 (Nap) C31.13.1', due to their similarity and the fact that they gloss the same text, and three versions of the Benedictine Rule in 'BenR B10.3.1.1', 'BenRW B10.3.4' and 'BenRWells B1o.3.3', for the same reason. However, individual glosses to the psalter and canticles have been counted separately, since the gloss to the Vespasian Psalter is obviously not the same as the one to the Royal Psalter. If a lexeme occurs in a psalter gloss and a canticle gloss in the same manuscript, both glosses have been counted as one text, even though the two have been assigned different Cameron numbers. With respect to this policy, I believe my results would not be significantly different if I had made different choices.

The categorisation of the lemmata in prior scholarship is based, for the most part, on the secondary sources themselves; the claims made in the sources have not been checked against the $D O E$ or $D O E C$. Nevertheless, the $D O E$ and $D O E C$ have been used for the categorisation of a number of lexemes about which very little information, e.g., in terms of their frequency, was given in the sources. ${ }^{13}$ I limited myself to those lemmata which are found in the $D O E$. Lemmata that do not begin with the letters A-I, which are not found in the $D O E$, have been placed in a separate category. Lastly, whenever sources have indicated that a specific lemma or specific lexical usage is part of the Winchester vocabulary, this has been indicated in the relevant footnotes in Appendix B.

In contrast to the other lexemes found in prior scholarship, the words found in previous research on Ælfric's Grammar have been checked in the DOEC as far

13 See, for instance, gramlic and gramlice in categories $\mathrm{B}_{1}$ and $\mathrm{C} 1$, respectively, in Appendix B. Consequently, some of the lemmata that are part of Appendix A also appear in Appendix B. 
as possible. ${ }^{14}$ It seemed preferable to categorise only those grammatical terms which had a significant number of occurrences in the works of Ælfric, and reject such lexemes mentioned in the literature as nama 'noun' and word 'verb' (Chapman, 2010: 423), which are arguably quite general. My rule of thumb is as follows: if a lexeme has been determined to belong to category $\mathrm{D}$ and fewer than $50 \%$ of its occurrences are found in the works of Ælfric (not necessarily Ælfric's Grammar), then this word is not categorised. If, however, a lexeme has been determined to belong to categories A, B or C, it is always categorised, even if, for instance, only one of nine occurrences of this word is found in the works of Ælfric. ${ }^{15} \mathrm{~A}$ number of words which were quite difficult to check in the DOEC (because their forms were similar to other lemmata and these forms could not easily be distinguished from each other) have been discounted.

One guiding principle of the categorisation is that the $D O E$ is followed whenever this is possible. This principle has led to some inconsistencies in the categorisation of the words in Ælfric's Grammar. For instance, if a word mentioned in a secondary source is a present participle such as feestnigende 'affirmative' (Chapman, 2010: 441), and this word can only be found as part of the DOE entry for the whole verb (feestnian), which is not an Ælfric word according to the rule above, then it is not categorised. However, for words beyond the letter I, i.e., those which could not be checked in the $D O E$, present participles are taken as separate from their main verbs if these present participles are specifically mentioned in prior scholarship, e.g., ofcumende 'derivative' (Chapman, 2010: 443), since the $D O E$ is not always consistent in categorising present participles or lemmata derived from present participles. ${ }^{16}$

The secondary sources that I consulted often featured various types of information about Ælfric's lexical usage, which could not easily be compared to each other. Information such as Ælfric's preference of one lemma over another

14 For these words, I primarily made use of Appendix 2 in Chapman (2010: 438-445), ignoring the multiword terms on pp. 443-445; I also consulted Sauer (2009: 171) and Williams (1958: 461-462).

15 I applied the same rule to the four lemmata which are labelled by the $D O E$ as frequently or exclusively occurring in the prose translation of Genesis.

16 For instance, the lemma healfclipiende 'semivocalic' can be found in this form in the $D O E$ (s.v. healf-clipiende), rather than being subsumed under a reconstructed infinitive *healfclipian. Similarly, some citations in the entry for the agentive noun dēelnimend 'participant; participle' feature forms ending in -ende in the nominative singular (DOE, s.v. dēel-nimend); this ending indicates that they are present participles, rather than agentive nouns (which would end in -end in the nominative singular). Hence, instances of the present participle délnimende seem to have been subsumed under the entry for the agentive noun dēlnimend, rather than having been assigned to a reconstructed infinitive *dēelniman in the DOE. 
for the expression of a certain concept seemed relevant to record, but could not be categorised in categories A-D due to the lack of information pertaining to the number of non-Ælfrician texts in which these preferred lemmata occurred, and their total number of occurrences in the DOEC. In order to ensure the accurate categorisation of the Ælfrician vocabulary identified by prior scholarship, it was necessary to add an additional four categories to the categorisation outlined above. The following four categories were created:

- Category E contains particular lexemes that Ælfric prefers over synonymous lexemes. This category is further subdivided into categories E1 and E2, which relate to whether these preferences are constrained by semantic, contextual or other factors:

- Category E1 features preferences which are, generally, unrelated to specific semantic or contextual usages.

- Category E2 features preferences which are, generally, related to specific semantic or contextual usages, or certain other factors.

One example of an entry in category E1 is Ælfric's preferred usage of gefrēdan, rather than fëlan, to express the verb 'to feel. ${ }^{17}$ This preference is independent of contextual or semantic factors. Conversely, an example of an entry in category E2 is Ælfric's preference of the verb (ge)rihtlēcan over ( $g e$ ) rihtan when expressing the verb 'to correct' in figurative senses (and, conversely, the verb (ge)rihtan over (ge)rihtlēecan in literal senses) (Hofstetter, 1987:51).18

- Category F contains particular morphological forms of lexemes that Ælfric prefers over other morphological forms. The root is the same for both preferred and dispreferred equivalents; the synonyms merely differ in terms of the other morphemes that they may contain, such as prefixes. For instance, Ælfric prefers the form bebod 'command', with the prefix be-, over gebod, with the prefix $g e$ - (Sato, 2011: 308).19

17 Pope (1967: 99), who cites Dietrich (1855: 544-545, fn. 140). Klein (2012: 491) notes that Ælfric never uses fêlan or related forms.

18 While the verb (ge)rihtlēecan is part of the Winchester vocabulary according to Hofstetter (1987: 38), it would seem that the difference in usage between (ge)rihtlēcan and (ge)rihtan is particular to Ælfric (51). Jost (1950: 137-138) labels gerihtlēecan as an 'Ælfricwort'.

19 According to Sato (2011: 308), there are no instances of gebod in both series of Ælfric's Catholic Homilies and in his Lives of Saints. 
- Category G contains widely used lemmata that Ælfric uses in particular contexts or with specific meanings. For example, the sense 'to bury' for the verb bestandan is primarily attested in the works of Ælfric (Jost, 195०: 144). ${ }^{20}$

- Category H contains lemmata that do not fit in the preceding categories. This is where claims have been placed such as 'most instances of pwȳrlic can be found in Ælfric' (Jost, 1950: 130). Since there is no information pertaining to the number of occurrences of this lemma in non-Ælfrician texts, it is not possible to place it in categories A-D. At the same time, it is impossible to place $p w \bar{y}$ rlic in categories E-G, since the source does not mention if Ælfric prefers this lemma over an equivalent lemma, or if he uses it in a specific sense.

Taken together, categories A-H allow for the creation of an overall characterisation of Ælfric's lexical usage, featuring lemmata that are primarily or exclusively restricted to his works, preferences of particular lemmata over others, and lemmata that have semantic or contextual usages which are specifically Ælfrician.

\subsection{Results}

The results of the categorisation are presented in Tables 1 and $2 .{ }^{21}$

TABLE 1 Results of the categorisation of Ælfrician vocabulary in the $D O E$ and prior scholarship for categories A-D

Categories $\quad 1(\geq 5$ occ. $) \quad 2(1-4$ occ. $) \quad$ Total

\begin{tabular}{llrr}
\hline A (o non-Ælf. texts) & 32 & 120 & $15^{2}$ \\
B (1 non-Ælf. text) & 49 & 25 & 74 \\
C (2-4 non-Ælf. texts) & 66 & 0 & 66 \\
D ( $\geq$ 5 non-Ælf. texts) & NA & NA & 118 \\
\hline
\end{tabular}

Total A-D

410

20 See the $D O E$ (s.v. be-standan, sense 3). The $D O E$ (s.v. be-standan) lists sense 1 as 'to stand around (a place acc.)', sense 2.a as 'utan bestandan "to surround (someone acc.)"' and sense $2 . \mathrm{b}$ as 'to beset (someone / something acc.)'.

21 Note that, for categories A-D, lemmata found in prior scholarship which have also been labelled by the $D O E$ as Ælfrician (i.e., lemmata which appear in both Appendix A and Appendix B) are seen as duplicates, and have only been counted once. 
TABLE 2 Results of the categorisation of Ælfrician vocabulary in prior scholarship for categories $\mathrm{E}-\mathrm{H}$

Categories

Total

E1 (preferences unrelated to semantic/contextual usages) $\quad 26$

E2 (preferences related to semantic/contextual usages) 8

$\mathrm{F}$ (preferences related to morphological forms of lexemes) 12

G (lemmata used in particular contexts or with specific meanings) 3

$\mathrm{H}$ (lemmata that do not fit in the other categories) 6

Total E-H

Out of the eight categories A-H, which contain a total of 465 items, the two largest categories are those which, respectively, contain words which are the most (category A) and the least (category D) restricted to the works of Ælfric. The vast majority of the $15^{2}$ lexical items in category A can be found in category A2, which features 120 lemmata $(78.95 \%)$. These Ælfrician words are quite rare, occurring between one and four times in the works of Ælfric. For categories $B$ and $C$, this tendency is reversed: category $\mathrm{B}_{2}$ contains fewer items than $\mathrm{B} 1$, and there are no lexical items at all in category $\mathrm{C} 2$. This outcome is not surprising, since a higher number of non-Ælfrician texts in which a word occurs directly correlates with a higher overall frequency of that lemma. In categories $\mathrm{E}-\mathrm{H}$, there are 55 items, of which the majority can be found in category E: 34 items $(61.82 \%) .{ }^{22}$ Within category $\mathrm{E}$, the best represented category is category $\mathrm{El}$, which contains 26 items $(76.47 \%)$. This result implies that Ælfric's preferences for particular lemmata over other, synonymous lemmata that are unrelated to specific semantic or contextual constraints have received the most attention in prior scholarship.

Note that there is an important difference in the way the items in categories $\mathrm{A}-\mathrm{D}$ and those in categories $\mathrm{E}-\mathrm{H}$ have been counted. Whereas in categories A-D each lemma is counted individually, this is not the case for categories $\mathrm{E}-\mathrm{H}$; in the latter categories, the entire entry, regardless of the fact that it may contain more than one Ælfrician lemma, is counted as a single unit.

22 Note that a search in the $D O E$ for 'ælfric' in the "Definition" field yields 84 entries with senses primarily or exclusively found in the works of Ælfric, which could have been placed in category G. However, in order to keep the data to be categorised at a manageable level, I decided to consult only prior scholarship for categories E-H. 
For instance, the entry "'élc/gehwä/gehwilc 'every' preferred to $\bar{x} g h w i l c " 23$ in category E1 is counted as a single unit, despite the fact that there are three preferred lemmata. One reason for counting in this way is that the logic of having 'preferred' lemmata versus 'dispreferred' lemmata breaks down when counting entries in category E2. Recall the aforementioned example of ( ge)rihtlēecan being preferred over (ge)rihtan when expressing the verb 'to correct' in figurative senses: this fact does not entail that (ge)rihtan is a dispreferred lemma, since Ælfric, conversely, prefers to use (ge)rihtan over (ge)rihtlēcan in literal senses. In other words, the preference goes both ways. Furthermore, all lemmata in an entry, whether preferred or dispreferred, have identical or strongly related senses, which also implies that it is sensible to count them as a single unit.

\subsection{Reflection on the Use of the DoE for the Collection of Alfrician Vocabulary}

The collection of data on the lexis of a particular author from a dictionary such as the $D O E$ is perhaps somewhat unorthodox when compared to such methods as consulting secondary sources or analysing a corpus of the author's works. In this section, I will briefly reflect on some of the issues that were encountered during this study.

The choices made by the $D O E$ with respect to lemmatisation directly influence which lemmata are considered to be Ælfrician in this study. Some of these lemmata are of questionable relevance. For instance, due to the policy of the $D O E$ to create two separate entries for lemmata with and without the prefix ge-, the lemmata edcennan and geedcennan are lemmatised separately in the $D O E$. Although the A1 lemma edcennan occurs six times, only in the works of Ælfric (DOE, s.v. ed-cennan), the longer form ge.edcennan occurs twice, both times in non-Ælfrician texts (DOE, s.v. ge.ed-cennan). Lastly, the past participle geedcenned also receives an entry of its own, because it cannot be determined if this past participle belongs to edcennan or ge.edcennan. Although the past participle, which has 21 occurrences in total, does appear in Ælfrician texts, it is also found in at least six non-Ælfrician texts (DOE, s.v. ge.ed-cenned). It is very likely that, if all these forms had been subsumed under a single entry, e.g., (ge.) edcennan, this entry would not have been labelled as Ælfrician in the DOE. In addition, the lemma edcennan is, according to its label in the $D O E$, primarily

23 Jost (1950: 162-166), reiterated by Pope (1967: 100). According to Jost (1950: 162-166), the first lemma, $\bar{e} l c$, is used most frequently by Ælfric; he also mentions that there are only three occurrences of äghwilc in the works of Ælfric; see also Jost (1950: 162-166) for more detailed information on the usage of these lemmata. 
found in a late twelfth-century manuscript (DOE, s.v. ed-cennan) $\cdot{ }^{24}$ It may be argued that a lemma which is mainly restricted to a copy written almost two centuries after Ælfric's lifetime cannot be seen as characteristic of his lexical usage. Both of these factors - the lemmatisation policies of the $D O E$ and the restriction of certain lemmata to late copies of Ælfric's works - affect the way the $D O E$ might be used as a source for Ælfrician vocabulary. ${ }^{25}$

Manuscript-specific readings such as edcennan can be problematic in other ways. For instance, if two authoritative copies use different lemmata, it may be difficult to determine the 'true' Ælfrician reading. A relevant example is the lemma flocc 'flock', which has been placed in category $\mathrm{C} 1$, based on the fact that it occurs in four non-Ælfrician texts. ${ }^{26}$ However, one of its occurrences, 'floccum', occurs in manuscript $P$ of Ælfric's translation of the book of Judges, while manuscript $\mathrm{Z}$, which is the base manuscript used by the $D O E$, employs a form that is based on the lemma folc, namely, 'folcum.27 If 'folcum' is the original Ælfrician reading, the occurrence of 'floccum' in manuscript $P$ should be counted as non-Ælfrician, which brings the total number of non-Ælfrician texts to five, and requires this lemma to be placed in category D. Although both readings make sense in the context, a case can be made for 'floccum' being the original Ælfrician reading, due to the fact that it is the more plausible variant: according to the $D O E$, the two instances of folc with the sense "band of men, company, division of an army" (one of which occurs in the quotation found in Judges, and the other in the D version of the Anglo-Saxon Chronicle) were "perhaps intended for flocc q.v." (DOE, s.v. folc, sense 13). ${ }^{28}$ The issue of counting an instance of a particular lemma as Ælfrician if it only occurs in one or two manuscript copies is especially relevant to the works of Elfric, which often exist in multiple manuscripts. ${ }^{29}$ This factor may, therefore, also influence the use of $D O E$ data in studies on Ælfrician vocabulary.

24 The label is "in Ælfric, mainly in MS of s.xii2". According to the DOE (s.v. ed-cennan), four out of its six occurrences are found in manuscript B, which refers to Oxford, Bodleian Library, Bodley 343 (see Kleist, 2019: 208).

For similar examples, see, for instance, ge.bōgian (A2), bōgian ${ }^{2}\left(\mathrm{C}_{1}\right)$; cwēmednes (A2), ge.cwēmednes ( $\mathrm{B} 1)$; edcwician, edcucian ( $\mathrm{B} 1)$, ge.edcwician, ge.edcucian $(\mathrm{C1})$, ge.edcwicod, ge.edcucod (D); ge.hrepian, ge.hreppan (A2), hrepian, hreppan (D) in Appendix A. As TOE does normally subsume variants with the prefix ge- under a single form (e.g., (ge)cwēmednes), this poses a problem for tagging the $D O E$ entries in Evoke (see section 3.1).

26 According to the $D O E$ (s.v. flocc), and a search in the DOEC for 'floc'.

27 Manuscript P refers to Oxford, Bodleian Library, Hatton 115; manuscript $Z$ refers to Oxford, Bodleian Library, Laud Misc. $5 \circ 9$ (see Kleist, 2019: 226, 236).

28 See also the entry for flocc in Appendix A, category C1.

29 See, for instance, the $D O E$ (s.v. for-scyldig); this adjective occurs in some copies of Ælfrician texts, whereas other copies instead have the adjective scyldig or the verb forscyldigian. 
Lastly, there were a number of more general issues with this study. As has been mentioned above, Ælfric was a prolific writer whose works have been well-preserved. This fact is borne out by his presence in the $D O E C$, in which his works may be said to be overrepresented. The works identified as having been written by Ælfric constitute $22.66 \%$ of the prose corpus (B) and $15.91 \%$ of the entire $D O E C$ - these percentages would be even higher if the word counts of the Ælfrician parts of the Heptateuch were included. ${ }^{30}$ In other words, there may be said to be a higher-than-average chance of a lexeme being found exclusively in the works of Ælfric.

An issue that is related to this overrepresentation is that some lemmata which, according to the DOEC, are found exclusively in the works of Ælfric were possibly used by other writers as well. For instance, the Ar adverb cēnlīce 'boldly', which has eight occurrences (DOE, s.v. ceenlīce), is derived from the more common adjective cêne 'bold', which occurs around fifty times in a number of different, mainly poetic, Old English texts (DOE, s.v. ceene). The higher frequency of occurrence of cene, coupled with the transparent derivation of cênlìce, makes it plausible to believe that this adverb must also have been used by other authors, whose texts have now simply been lost to us. ${ }^{31} \mathrm{~A}$ similar example is provided by the A1 adjective härwenge 'grey-haired', which occurs six times in Ælfrician texts (DOE, s.v. här-wenge). The existence of a derived noun härwengnes 'greybeardedness', which occurs only once in a non-Ælfrician glossary (DOE, s.v. härwengnes), seems to imply that the adjective must have been more common than the corpus shows. If exclusively Ælfrician lemmata, such as cēnlìce and härwenge, have strongly related lemmata which are not restricted to the works of Ælfric, then this factor may reduce the significance of these Ælfrician lemmata for studies into Ælfric's vocabulary.

One final point is that the $D O E$ has not consistently labelled words that primarily or exclusively occur in the works of Ælfric. The noun alêfednes 'infirmity', for instance, has only one occurrence in the corpus, in Ælfric's works, but it does not receive a specific label in the $D O E$. This lack of labelling implies that there are still more Ælfrician lemmata to be found in the $D O E$, which may perhaps be labelled in future editions of the dictionary. ${ }^{32}$

30 Calculated based on the word counts of 'OE words' given by the DOEC; see https://tapor library.utoronto.ca/doecorpus/wordcount.html.

31 Cf. the equivalent adverb in Present Day English, keenly, which is, of course, not restricted to any particular author.

32 Lemmata that are in some way restricted to or frequently occur in the works of Ælfric, as indicated by prior scholarship or by analysing their occurrences in the DOE Or DOEC myself, but which have not been labelled as such by the $D O E$, are preceded by a plus symbol in the appendices. I have not systematically searched the $D O E$ for these non-labelled, Ælfrician lemmata, but I did think it was relevant to include those I had found. 


\subsection{Methodology}

In order to discover the characteristics of the Ælfrician vocabulary that was categorised in the previous section, the lemmata were tagged in Evoke. Since Evoke uses a Linguistic Linked Data version of $T O E,{ }^{33}$ which lemmatises differently from the $D O E$, a number of choices had to be made in order to tag the words found in the $D O E$ and prior scholarship in Evoke. These choices will be outlined in this section. More specific information about the tagging of individual lemmata can be found in the footnotes in the appendices. For the purpose of tagging the Ælfrician vocabulary in Evoke, only categories A-D have been taken into account, since the lemmata in these categories form a cohesive unit in that they are either restricted to or occur frequently in the works of Ælfric. The lemmata in categories E-H are more difficult to quantify in this sense. For instance, Ælfric may prefer the verb gefrēdan 'to feel' to its synonym félan (see section 2.2), but this fact does not imply that the verb gefrēdan is in some way restricted to the works of Ælfric; this entry in category E1 simply indicates a preference.

Each lexical entry (i.e., not the individual lexical senses) for an Ælfrician lemma in Evoke receives three tags:

- \#Ælfrician: All Ælfrician lemmata receive this tag, which allows for the immediate selection of all Ælfrician vocabulary in Evoke.

_ \#Ælfrician_A/\#Ælfrician_B/\#Ælfrician_C/\#Ælfrician_D: These tags indicate the category $(\mathrm{A}-\mathrm{D})$ to which a lemma belongs.

- \#freq5plus/\#freqito4: These tags indicate the subcategory (1 or 2 ) to which a lemma belongs. Subcategory 1 is tagged as \#freq5plus (since the lemma which receives this tag has five or more occurrences in the DOEC) and subcategory 2 is tagged as \#freqito4 (the lemma has between one and four occurrences in the $D O E C$ ).

In addition, a number of lemmata also receive the tag \#comment, which is accompanied by a brief explanation outlining the discrepancy between the ways in which these lemmata are treated in the DOE and TOE (see below).

There were a number of issues with tagging the Ælfrician vocabulary in Evoke. One issue is that some $D O E$ lemmata do not have equivalent lemmata

33 Henceforth simply referred to as ' $T O E$ '; cf. Stolk in this issue. TOE is constantly being updated; the Linguistic Linked Data version of TOE available in Evoke at the time of writing this article is based on the version of TOE that was ported by Sander Stolk on 26 May 2017. A number of issues mentioned in this article have already been solved in the latest version of $T O E$. 
in Evoke, which means that they could not be tagged..$^{34}$ Other issues relate to the different lemmatisation choices made by the $D O E$ and $T O E$. For instance, the $D O E$ considers words which occur with and without the prefix ge-, such as the verbs gehüslian and hüslian 'to administer the Eucharist', as separate lemmata (DOE, s.vv. ge.hüslian, hüslian). Since the past participle gehüslod could theoretically belong to either of these verbs, it too receives its own entry (DOE, s.v. ge.hüslod). In TOE, however, these three entries correspond to a single entry: (ge)hüslian, which creates problems for categorisation, since the three $D O E$ entries each have their own category (gehüslian is A1, hüslian is $\mathrm{B} 1$, and gehüslod is not in the appendices). Conversely, the opposite may be true: a single entry in the DOE may correspond to two or more entries in TOE. For instance, a search for the verb bedydrian 'to delude' in Evoke gives two results: bedydrian and bedydrian ... wip. The second of these entries, with the sense 'to conceal', is listed as sense 2 in the $D O E$ (s.v. be-dydrian).

In order to employ a consistent strategy for dealing with these discrepancies, it was once again established as a main principle that the $D O E$ is followed whenever possible (see section 2.2), since the categorisation of the Ælfrician vocabulary is primarily based on the $D O E$. This principle led to the following solutions to the problems mentioned above: when the $D O E$ has multiple lemmata which correspond to a single lemma in TOE, the labels for these lemmata are consolidated. In other words, the lemmata gehüslian (A1), hüslian (B1) and gehüslod (not part of the appendices) are taken as a single lemma, and their occurrences in non-Ælfrician texts are combined. Therefore, the equivalent lemma (ge)hüslian has been tagged in Evoke as C1. Comments have been added to Evoke entries which subsume multiple $D O E$ lemmata for the purposes of clarity; e.g., in the case of ( $g e$ h)hüslian: "\#comment Conflation of three DOE entries: gehūslian ( $\mathrm{A1})$, hūslian $(\mathrm{B} 1)$ and gehūslod (not in appendices)." Conversely, when a single $D O E$ entry corresponds to multiple TOE entries, all relevant TOE entries in Evoke are assigned the same category as the $D O E$ entry; the $D O E$ lemma has not been 'split up' into TOE lemmata which are then recategorised. In other words, both bedydrian and bedydrian ... wip are tagged as $\mathrm{C} 1$ in Evoke; the fact that bedydrian ... wip with the sense 'to conceal' only occurs once in total, in the works of Ælfric (DOE, s.v. be-dydrian, sense 2), has not been taken into account.

Note that for entries in $T O E$ in which a preposition is part of the lemma for a verb (such as bedydrian ... wip), only those entries have been tagged which have demonstrably been used by Ælfric, i.e., there is an Ælfrician quote for this

34 E.g., fornēan 'almost', which was not yet available in the Linguistic Linked Data version of TOE used for this article. See footnote 33 . 
particular verb + preposition combination in the equivalent $D O E$ entry. This decision was also made in order to reduce the number of errors with respect to tagging senses of Ælfrician lemmata which do not actually occur in Ælfric's texts. For instance, with respect to the D lemma abügan, one of the four results in TOE, ābügan fram, has not been tagged, since the sense that is attested for it in TOE, 'to move from', seems to correspond to sense 2.b in the $D O E$ (s.v. $a$-bügan), which does not list any Ælfrician quotes. The same principle has been applied to other lemmata: if a TOE entry is solely associated with senses which are not found in the works of Ælfric for that particular lemma, then this entry is not tagged in Evoke. ${ }^{35}$

\subsection{Results}

The Ælfrician vocabulary which has been tagged in Evoke can be subjected to a number of statistical analyses, which highlight the similarities and differences between Ælfric's vocabulary and all words in $T O E$ as a whole. Therefore, these analyses provide insights into the characteristics of Ælfric's vocabulary. Due to the discrepancies between the DOE and TOE (see section 3.1), the number of tagged entries per category in Evoke differs from the number of entries which have been categorised based on the $D O E$ and prior scholarship, as found in Appendices A and B (see Table 3 below and cf. Table 1 above). For reasons of space and since this is an exploratory study, Ælfric's lexis will be analysed as a whole in this section, without taking into account the differences between categories A-D.

35 Discrepancies between the $D O E$ and $T O E$ and the subsequent choices with respect to tagging in Evoke have been indicated in the footnotes in the appendices (and the corresponding entries are preceded by asterisks), but, for reasons of space, no information is given about the reasoning which underlies these choices (e.g., the sense of a TOE entry does not occur in the works of Ælfric). Occasionally, tagging multiple $D O E$ entries as one $T O E$ entry in Evoke leads to category D words with fewer than $50 \%$ of their occurrences in the works of Ælfric. These TOE entries have nevertheless been tagged, since they subsume at least one lemma which the $D O E$ has labelled as Ælfrician (the only exception being ge.ered in category A2, Appendix A). However, if a lemma found in scholarship on Ælfric's Grammar corresponds to a TOE entry which subsumes another lemma (e.g., a variant with the prefix $g e$-) and these lemmata taken together are categorised as D with fewer than $50 \%$ of their occurrences in the works of Ælfric, then this word is not categorised at all (i.e., it is not part of the appendices either). A slightly stricter approach towards the categorisation of the words found in Ælfric's Grammar is warranted, since the claim in the literature (Williams, 1958; Sauer, 2009; Chapman, 2010) is not that all of these words are frequently found in the works of Ælfric, but rather that they simply occur in Ælfric's Grammar as translations of particular Latin lemmata. 
TABLE 3 Results of the tagging of Ælfrician vocabulary in Evoke

\begin{tabular}{lccc}
\hline Categories & $\mathbf{1}(\geq \mathbf{5}$ occ. $)$ & $\mathbf{2}(\mathbf{1}-\mathbf{4}$ occ. $)$ & Total \\
\hline A (o non-Ælf. texts) & 28 & 102 & 130 \\
B (1 non-Ælf. text) & 45 & 25 & 70 \\
C (2-4 non-Ælf. texts) & 64 & 0 & 64 \\
D ( $\geq$ 5 non-Ælf. texts) & NA & NA & 153 \\
\hline
\end{tabular}

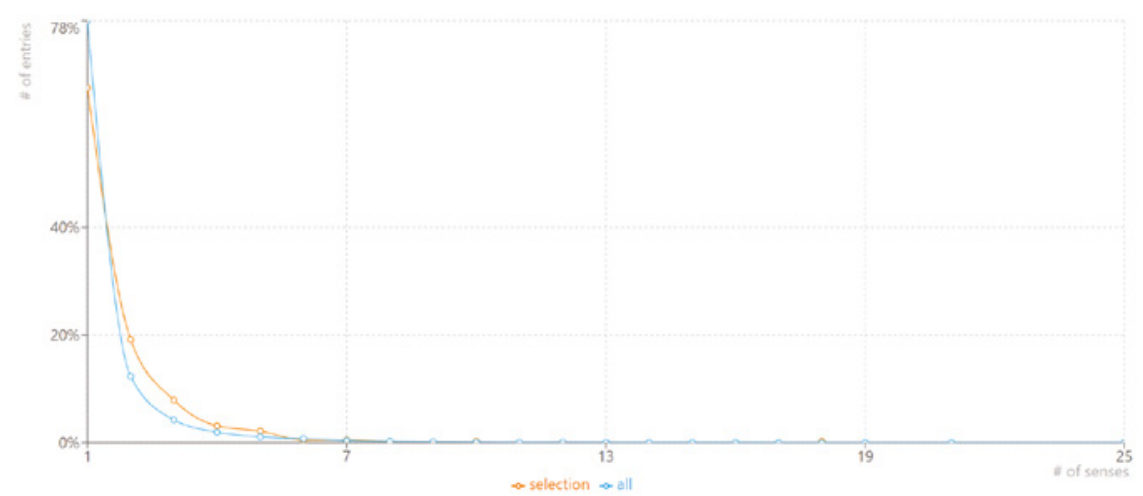

FIGURE 1 The degree of ambiguity of Ælfric's vocabulary (orange) and TOE (blue)

First of all, Evoke can be used to determine the degree of ambiguity of Ælfric's lexis. The degree of ambiguity is related to the number of senses that a lemma may have. For instance, if Ælfrician words generally have a low number of different possible senses, this result would imply that Ælfric's lexical usage can be characterised as unambiguous, and could mean that he is particularly concerned about writing as precisely as possible. A high degree of ambiguity would indicate the opposite: a lack of a particular concern for precision in lexical usage, and perhaps a deliberate effort to allow for multiple interpretations of his words.

As Figure 1 shows, Ælfric's vocabulary is somewhat more ambiguous than the vocabulary in TOE. Around two-thirds - 65.95\% - of the lexical entries tagged as Ælfrician have only one sense associated with them, as opposed to $78.40 \%$ of the entries in TOE as a whole. Conversely, Ælfric's vocabulary contains relatively more lemmata with two, three, four or five senses than TOE does. According to Evoke, an Ælfrician lemma has, on average, 1.66 senses associated 
with it, while a lemma in $T O E$ has 1.45 senses. While this is perhaps not a significant difference, it seems that, on average, Ælfric's vocabulary is somewhat more ambiguous than Old English vocabulary in general. Nevertheless, this difference is not great enough to allow for the conclusion that Ælfric was deliberately ambiguous or unconcerned with lexical precision in his works.

Evoke can also determine the degree of synonymy of Ælfric's vocabulary. One crucial difference between this analysis and the previous one is that the degree of synonymy relates to lexical senses, rather than lexical entries. Since only lexical entries have been tagged in Evoke, not lexical senses, the analysis in Evoke takes into account all 693 senses that are associated with the 417 Ælfrician lemmata, including those senses which have not been attested in the works of Ælfric. ${ }^{36}$ The degree of synonymy is related to the number of synonyms that are available for a lexical sense. If Ælfric mainly uses lexical senses with a high number of synonyms, the implication would be that Ælfric, in choosing one particular synonym over other available equivalents, often made deliberate lexical choices in his writings. On the other hand, if the works of Ælfric generally feature lexical senses with few synonyms, this fact would make it more difficult to argue that Ælfric frequently made particular conscious lexical choices.

The graph in Figure 2 shows that a quarter of the senses associated with Ælfric's vocabulary $(25.69 \%)$ have zero synonyms available for them (i.e., there is only one lemma associated with these senses). This percentage is almost the same for the senses in TOE: $24.63 \%$ of all senses in TOE have zero synonyms

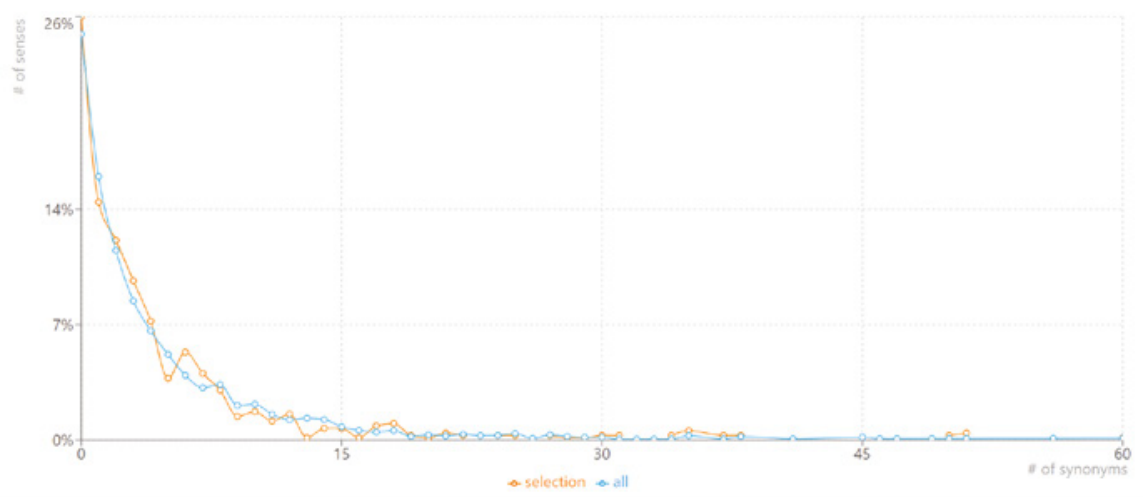

FIGURE 2 The degree of synonymy of Ælfric's vocabulary (orange) and TOE (blue)

36 An attempt has been made to mitigate this effect somewhat: if a $D O E$ lemma corresponds to multiple TOE entries, the TOE entries are only tagged if they are associated with senses that actually occur in the works of Ælfric (see section 3.1). 
available for them. The graphs for the senses of the Ælfrician lemmata and the senses for the TOE lemmata are roughly equivalent. This fact is borne out by Evoke's statistical analysis, which shows that, on average, a sense of a given Ælfrician lemma has 4.88 synonyms available for it, while a sense of a lemma in TOE has 4.92 synonyms associated with it. In other words, it is very likely that Ælfric made deliberate lexical choices in his writings, something which is also borne out by categories $\mathrm{E}$ and $\mathrm{F}$, which feature lemmata that Ælfric prefers over their synonyms. Nevertheless, Ælfric probably did not make particular lexical choices to a greater extent than was normal in Old English.

Another analysis which can be carried out in Evoke relates to the degree of specificity of particular vocabulary. This analysis also uses the total number of senses associated with lexical entries to show the distribution of these senses in the taxonomy of TOE (which Evoke refers to as the 'tree depth' of these senses), with 1 being the most abstract level and 11 the most specific level in meaning. For instance, if the senses associated with Ælfric's vocabulary are found, overall, at higher taxonomy levels, then Ælfric's vocabulary may be said to have a high degree of specificity. This result might imply that Ælfric created some of his vocabulary in order to fill gaps in the Old English lexicon. On the other hand, if many senses are found at lower taxonomy levels, this tendency would point to a preference on Ælfric's part for using specific terms for more general concepts. This vocabulary is less likely to have been created by Ælfric, as the chances are higher that Ælfric simply made use of particular pre-existing lexemes.

Figure 3 shows that the senses associated with Ælfric's vocabulary follow much the same distribution in TOE's taxonomy as the distribution of all senses found in TOE. On average, a sense found in Ælfric's vocabulary has a taxonomy level of 5.14, which is virtually identical to the average for all TOE senses:

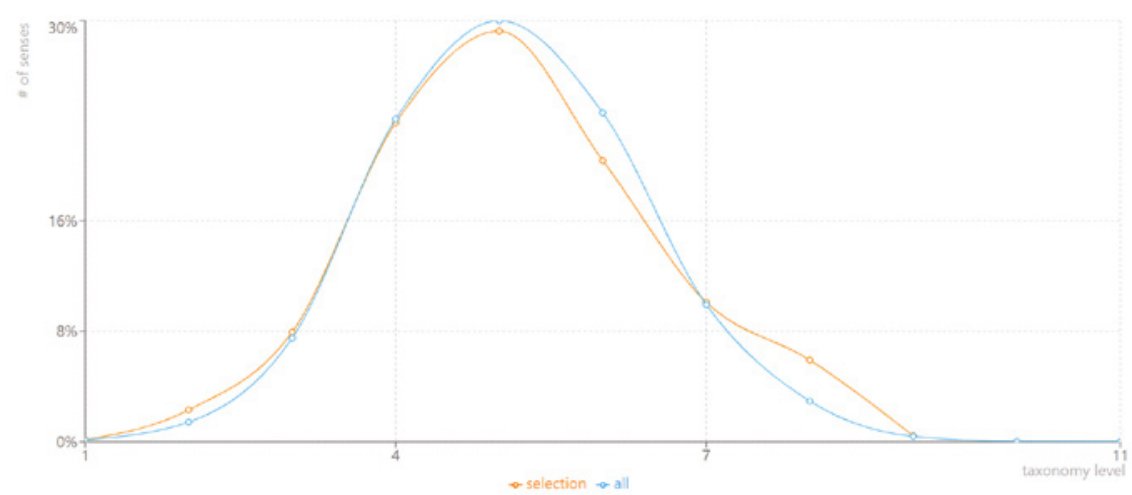

FIGURE 3 The degree of specificity of Ælfric's vocabulary (orange) and TOE (blue) 
5.11. This result is to be expected, since words are seldom extremely general or extremely specific: most words fall somewhere in between these two extremes. Nevertheless, the graph does show that senses associated with Ælfric's vocabulary are found relatively less often at a taxonomy level of 6 (Ælfric: $20.35 \%$; TOE: $23.81 \%$ ) and relatively more often at a taxonomy level of 8 (Ælfric: $5.92 \%$; TOE: $2.95 \%$ ). Although it is true that the degrees of specificity of Ælfric's vocabulary and all of the vocabulary in TOE are, on average, virtually the same, it does seem that Ælfric's vocabulary is somewhat more specific than Old English vocabulary in general, since it features a higher-than-expected percentage of senses at taxonomy level 8 and a lower-than-expected percentage of senses at taxonomy level 6 .

Lastly, Evoke can show how the senses associated with Ælfric's vocabulary are distributed across the categories in TOE, in order to establish the semantic domains in which Ælfrician vocabulary predominates and the domains in which it is underrepresented.

One category that immediately stands out in Figure 4 as containing a particularly high proportion of the senses associated with Ælfric's vocabulary is "o9 Speech, vocal utterance": $15.73 \%$ of all the senses associated with Ælfric's vocabulary are found in this category, whereas the same category contains only $3.67 \%$ of all senses in TOE. If the bars belonging to this category are clicked, Evoke shows a new graph, featuring the distribution of senses across the subcategories of "og Speech, vocal utterance". This graph shows that the vast majority of the senses associated with Ælfric's lexis in "og Speech, vocal utterance" are found in the category "o9.03 A language" (Ælfric: 12.41\%; TOE: 1.34\%), and, more specifically, in a subcategory of "og.03 A language": "o9.03.02 Art of grammar" (Ælfric: 10.25\%; TOE: $0.29 \%$ ). This result is not surprising.

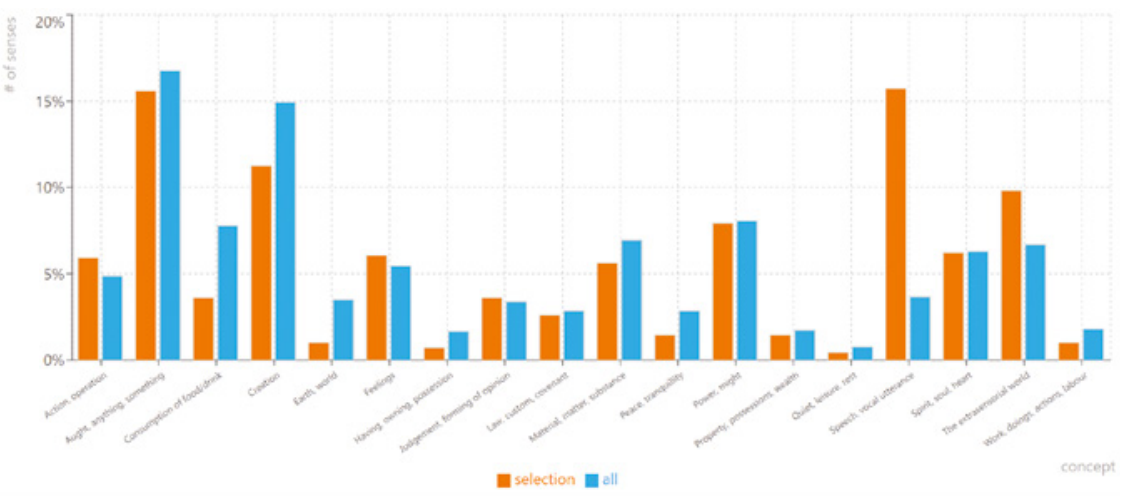

FIGURE 4 The distribution of the senses of Ælfric's vocabulary (orange) and all senses in TOE (blue) across the TOE categories 
Ælfric's Grammar teaches Latin grammar, but was written in Old English. For the purposes of this grammar, "Ælfric rendered into English practically every Latin term at least once [...]. Thus Ælfric used over two hundred English grammatical terms, most of which he presumably coined" (Chapman, 2010: 422). In other words, the restriction of a great amount of Old English grammatical terminology to Ælfric's Grammar means that grammatical terminology is overrepresented within Ælfric's characteristic vocabulary.

Another category in which Ælfric's vocabulary is overrepresented, albeit to a lesser extent than in the category "og Speech, vocal utterance", is the category "16 The extrasensorial world". In this category, 9.81\% of the senses associated with Ælfric's vocabulary can be found, compared to $6.68 \%$ of all senses in TOE. When clicked, the graph shows that $3.75 \%$ of the senses linked with Ælfric's lexis occur in the subcategory "16.01 A divine being" (тов:1.98\%), while 6.o6\% of the senses of Ælfric's vocabulary are found in the subcategory "16.02 Religion" (TOE: $4.71 \%$ ). The slight overrepresentation of Ælfric's vocabulary in these categories is most likely related to his literary output, which, among other texts, consists of homilies, saints' lives, Bible translations and other religious texts.

Some of the categories in which Ælfric's vocabulary is underrepresented include "O4 Consumption of food/drink" (Ælfric: 3.61\%; TOE: 7.79\%), "O2 Creation" (Ælfric: 11.26\%; TOE: 14.94\%), and "O1 Earth, world" (Ælfric: 1.01\%; TOE: $3.5 \circ \%$ ). The lack of Ælfrician vocabulary in the first category is perhaps not unexpected, but "O2 Creation" and "o1 Earth, world" seem like categories in which Ælfric could have used his own characteristic vocabulary, since words relating to these domains may be found in texts such as homilies. When analysing the subcategories of "O2 Creation", Ælfrician vocabulary is especially lacking in the categories "O2.07 A plant" (Ælfric: О.О०\%; TOE: 2.45\%) and "O2.06 Animal" (Ælfric: 0.58\%; TOE: 1.72\%). Moreover, within the subcategories of "O1 Earth, world", Ælfric's vocabulary is conspicuously absent in the category "01.01 Surface of the earth" (Ælfric: $0.43 \%$; TOE: $2.60 \%$ ). One possible reason for the lack of characteristically Ælfrician vocabulary in these categories is that Ælfric did not feel the need to choose or create his own terminology when referring to concepts in these semantic domains, but was simply happy to use lemmata which enjoyed a wider usage.

\subsection{Discussion}

Based on the statistical analyses of Ælfric's vocabulary in Evoke, it would seem that the characteristics of Ælfric's lexis are not vastly different from those of Old English vocabulary in general, as found in TOE. The averages of the degrees of ambiguity (Ælfric: 1.66 senses per lemma; TOE: 1.45 senses per lemma), synonymy (Ælfric: 4.88 synonyms per sense; TOE: 4.92 synonyms per 
sense) and specificity (Ælfric: average sense has taxonomy level of 5.14; TOE: average sense has taxonomy level of 5.11) show that Ælfric's vocabulary exhibits the same tendencies as Old English vocabulary as a whole. Nevertheless, there are differences: the very similar averages for Ælfric's vocabulary and all vocabulary in $T O E$ with respect to their degrees of specificity obscure the fact that Ælfric's vocabulary has a higher chance of having a sense at taxonomy level 8 (Ælfric: 5.92\%; TOE: 2.95\%), and a lower chance of having a sense at taxonomy level 6 (Ælfric: 20.35\%; TOE: 23.81\%). Furthermore, a comparison of the distributions of the lexical senses associated with Ælfric's vocabulary and the senses associated with all vocabulary in $T O E$ shows that Ælfric's vocabulary is overrepresented in the category "og Speech, vocal utterance" (Ælfric: $15.73 \%$; TOE: $3.67 \%$ ) - especially in its sub-sub-category "og.03.02 Art of grammar" (Ælfric: $10.25 \%$; TOE: $0.29 \%$ ) - and in the category "16 The extrasensorial world" (Ælfric: 9.81\%; TOE: 6.68\%). The relatively higher percentage of Ælfrician vocabulary with a taxonomy level of 8 is most likely due to the overrepresentation of his vocabulary in the category "O9.03.02 Art of grammar". A number of the typically Ælfrician words in this category, such as names of grammatical cases (e.g., wrēgendlic 'accusative' in TOE category "O9.03.02.03.01.01.01|03 Case: Accusative") and names for verbal moods (e.g., äsciendlic 'interrogative' in TOE category "O9.03.02.03.01.02.01|02 Mood: Interrogative"), can be found at a taxonomy level of 8 . All in all, Ælfric's vocabulary does exhibit a number of features of its own.

The present analysis of Ælfric's vocabulary in Evoke must be seen as an exploratory study: a first step towards understanding the characteristics of the typical lexis of Ælfric of Eynsham. Future refinements with respect to the data set and methodology of this study are necessary. ${ }^{37}$ Firstly, during the process of tagging the Ælfrician lemmata in Evoke, a number of unlabelled lemmata were encountered in the $D O E$ which may be added to a subsequent version of the appendices. ${ }^{38}$ In addition, the present analysis of Ælfric's vocabulary

37 Note also that the comparison between Ælfric's vocabulary and all Old English vocabulary in $T O E$ involves data sets which are vastly different in terms of their sizes: Ælfric's vocabulary in Evoke consists of 417 lexical entries associated with 693 senses, while TOE features 35422 lexical entries associated with 51480 senses.

38 Many of these lemmata have, nevertheless, been taken into account in the analysis in Evoke, since they have indirectly been tagged as part of TOE entries which subsume them. See, for instance, the $D O E$ entries for gehūslod (tagged as part of (ge)hüslian), gebyrpere (tagged as part of (ge)byrpre), bytlung (tagged as part of (ge)bytlung), ? gegyht, ? gegyhte (tagged as part of (ge)gyht), ānlēean (tagged as part of (ge)ānlēean), gehremman (tagged as part of (ge)hremman), efenlēeing, efenlēecung (tagged as part of (ge)efenlēecung), ge.egesod, ge.egsod (tagged as part of (ge)egesian), elpēodlice (tagged as part of elpēod(ig) lice), ge.andwyrd (tagged as part of (ge)andwyrdan), cneordnes (tagged as part of (ge)cneordnes) and efenläcan (tagged as part of (ge)efenlēecan). In addition, the adverbs stōwlīce 
in Evoke has, for reasons of space, not individually analysed categories A-D, which show the degree to which the Ælfrician lemmata are restricted to his works. Future analyses could focus on the four categories (and subcategories 1 and 2) separately and contrast them with each other, in order to find out how they differ. For instance, almost a third (32.36\%) of the senses of the lemmata in category A can be found in "O9.03.02 Art of grammar", which means that much of the vocabulary that exclusively occurs in the works of Ælfric is related to grammar. ${ }^{39}$ Indeed, much of Ælfric's grammatical terminology is virtually restricted to his works: of the 71 senses which are associated with Ælfric's vocabulary in the category "o9.03.02 Art of grammar", almost two thirds ( 46 senses $=64.79 \%)$ are found in category A (cf. Chapman, 2010:422). Another improvement to this study would be to tag in Evoke only those lexical senses which occur in Ælfrician texts, rather than tagging lexical entries which incorporate lexical senses that do not necessarily occur in the works of Ælfric. This process is time-consuming, but would improve the accuracy of the statistical analyses in Evoke, since these primarily work with lexical senses, rather than lexical entries. Lastly, future analyses should take the remaining categories (E-H) of Ælfric's vocabulary into account. Contrasting Ælfric's preferred lemmata in categories $\mathrm{E}$ and $\mathrm{F}$ with their dispreferred equivalents, for instance, would provide insights into the semantic differences between these lemmata.

\section{4}

\section{Conclusion}

This study has collected, categorised and characterised the vocabulary of Ælfric of Eynsham using the DOE, secondary literature, TOE and Evoke. Although the present study does not claim to be exhaustive, it is hoped that it has demonstrated the usefulness of resources such as the DOE, TOE and Evoke for researching the particular vocabulary of Anglo-Saxon authors. While it is true that the use of the $D O E$ for studies of this kind is not entirely without its flaws, the DOE's corpus-based approach allows for the quantification of lemmata in the works of particular authors such as Elfric, and its usefulness will increase with each new fascicle that is published. The results of the analysis of Ælfric's vocabulary in Evoke are perhaps not entirely surprising: the predominance of vocabulary relating to grammar and religion may be expected for an author who is primarily known for his Grammar and religious texts, such as homilies.

and wîflice, derived from stōwlic (B1) and wïflic (D) may be added (these have not been tagged in Evoke). 
There are a number of further avenues of research which may employ the corpus of Ælfrician vocabulary compiled for this study. For instance, the overview of Ælfrician lexis can be useful for the establishment of Ælfrician authorship of anonymous texts. In addition, the corpus can be used to establish the influence of Ælfric's vocabulary on later texts, such as post-Conquest works. ${ }^{40}$ Lastly, once the typical lexis of other known authors, such as Wulfstan, has been compiled, these vocabularies may be compared to each other, in order to discover the differences and similarities between Ælfric's lexical usage and that of other Old English authors. For all of these avenues of research, it is hoped that this study may be a useful starting point for finding $p \bar{a} c \bar{e} g e$, $\partial e$ Jēra worda andgit unlīc $\gamma^{41}$ of the most prolific writer of Anglo-Saxon England: Ælfric of Eynsham.

\section{Acknowledgement}

I would like to thank Thijs Porck for his help during the process of collecting and categorising the data and Sander Stolk for his help with Evoke, and I am also grateful to them both for their excellent suggestions in the early stages of writing this article. I would also like to thank Lucas Gahrmann for his help with tagging the Ælfrician lemmata in Evoke.

\section{References}

Baalen, A. van. After Elfric: Tracing the Lexical Influence of Elfric of Eynsham in Two Twelfth-Century English Texts, MA Thesis (Leiden University Centre for Linguistics, Leiden University, 2021).

Breeze, A. “Ælfric's truð 'Buffoon': Old Irish druth 'Buffoon'” Notes and Queries 42 (2) (1995), 155-157.

40 For an example of this type of research, see Van Baalen (2021), which uses an earlier version of the present article's corpus of Ælfrician vocabulary to analyse two early twelfthcentury English translations - one of which is Ralph d'Escures' homily on the Assumption of the Virgin Mary, discussed by Treharne (2006) - and their possible use of Ælfrician vocabulary.

41 Original quote: "stæfcræft is seo cæg, ðe ðæra boca andgit unlicð" [grammar is the key which unlocks the meaning of the books], cited from the first line of the DOEC version of Ælfric's Grammar. Since andgit also means 'understanding', the intended meaning of the modified quote is 'the key which unlocks the understanding of the words'. 
Chapman, D. “Uterque Lingua/Ægðer Gereord: Ælfric's Grammatical Vocabulary and the Winchester Tradition." The Journal of English and Germanic Philology 109 (4) (2010), 421-445.

Clark Hall, J. R., with supplement by H. D. Merritt, eds. A Concise Anglo-Saxon Dictionary, 4th edn (Cambridge: Cambridge University Press, 196o).

Dietrich, E. "Abt Aelfric. Zur Literaturgeschichte der angelsächsischen Kirche." Zeitschrift für die Historische Theologie 25 (1855), 487-594.

$D O E=$ Cameron, A., A. Crandell Amos, A. diPaolo Healey, et al., eds. Dictionary of Old English: A to I online (Toronto: Dictionary of Old English Project, 2018). http://tapor library.utoronto.ca/doe/.

DOEC = DiPaolo Healey, A., with J. Price Wilkin and X. Xiang, ed. Dictionary of Old English Web Corpus (Toronto: Dictionary of Old English Project, 20o9), https:// tapor.library.utoronto.ca/doecorpus/.

Evoke = Stolk, S. Evoke (Web application, 2018), http://evoke.ullet.net/.

Fleming, D. “Sundorhalgan, Winchester, and Ælfric." The Review of English Studies, n.s. 66 (277) (2015), 822-842.

Godden, M. “Ælfric's Changing Vocabulary." English Studies 61 (3) (1980), 206-223.

Gretsch, M. “Ælfric, Language and Winchester." In A Companion to Elfric, eds. H. Magennis and M. Swan (Leiden and Boston: Brill, 20o9), 109-137.

Gretsch, M. "Winchester Vocabulary and Standard Old English: The Vernacular in Late Anglo-Saxon England." Bulletin of the John Rylands Library 83 (1) (2001), 41-87.

Hawk, B. W. "Isidorian Influences in Ælfric's Preface to Genesis." English Studies 95 (2014), 357-366.

Hill, J. “Ælfric: His Life and Works." In A Companion to Alfric, eds. H. Magennis and M. Swan (Leiden and Boston: Brill, 2009), 35-65.

Hill, J. “Ælfric's 'Silent Days'” Leeds Studies in English, n.s. 16 (1985), 118-131.

Hofstetter, W. Winchester und der spätaltenglische Sprachgebrauch (München: Wilhelm Fink Verlag, 1987).

Jost, K. “Unechte Ælfrictexte.” Anglia 51 (1927), 81-103, 177-219.

Jost, K. Wulfstanstudien. Schweizer Anglistische Arbeiten 23 (Bern: A. Francke Verlag, 1950).

Klein, T. "Dialect and Word Choice in Old English: Two Case Studies with Old English Perception Verbs." Anglia 130 (2012), 471-498.

Kleist, A. J. The Chronology and Canon of Alfric of Eynsham, Anglo-Saxon Studies 37 (Cambridge: D. S. Brewer, 2019).

Magennis, H. "Contrasting Features in the Non-Ælfrician Lives in the Old English Lives of Saints." Anglia 104 (1986), 316-348.

$M E D$ = Lewis, R. E., et al., eds. Middle English Dictionary (Ann Arbor: University of Michigan Press, 1952-2001). Online edition in Middle English Compendium, eds. F. McSparran et al. (Ann Arbor: University of Michigan Library, 200o-2018), http:// quod.lib.umich.edu/m/middle-english-dictionary/. 
Ono, S. “Old English Verbs of Possessing." In English Historical Linguistics and Philology in Japan, eds. J. Fisiak and A. Oizumi (Berlin and New York: Mouton de Gruyter, 1998), 297-311.

Ono, S. "Undergytan as a 'Winchester' Word." In Linguistics across Historical and Geographical Boundaries. Volume 1: Linguistic Theory and Historical Linguistics, eds. D. Kastovsky and A. Szwedek (Berlin, New York and Amsterdam: Mouton de Gruyter, 1986), 569-578.

Ono, S. "The Vocabulary of Ælfric and Wulfstan." In Old English Studies from Japan: 1941-81, eds. T. Kubouchi, W. Schipper and H. Ogawa (Binghamton, New York: Center for Medieval and Early Renaissance Studies, State University of New York at Binghamton, 1988), 75-88.

Pope, J. C., ed. Homilies of Alfric: A Supplementary Collection. Vol. 1. Early English Text Society 259 (London and New York: Oxford University Press, 1967).

Sato, K. “Ælfric's Lexical Alterations in his Adaptations from the Old English Boethius.” Neophilologus 95 (2011), 305-311.

Sauer, H. "How the Anglo-Saxons Expressed Their Emotions with the Help of Interjections." Brno Studies in English 35 (2009), 167-183.

Schabram, H. Superbia: Studien zum altenglischen Wortschatz. Teil I: Die dialektale und zeitliche Verbreitung des Wortguts (München: Wilhelm Fink Verlag, 1965).

Seebold, E. "Die ae. Entsprechungen von Lat. sapiens und prudens: Eine Untersuchung über die mundartliche Gliederung der ae. Literatur." Anglia 92 (1974), 291-333.

Shaw, R. “Just as the Books Tell Us': A New Work by Ælfric?” Notes and Queries 61 (3) (2014), 328-336.

Takeuchi, S. "Archaism in the Vocabulary of Ælfric." In English Historical Linguistics and Philology in Japan, eds. J. Fisiak and A. Oizumi (Berlin and New York: Mouton de Gruyter, 1998), 341-359.

Timofeeva, O. 'Lexical Loans and Their Diffusion in Old English: Of 'Gospels', 'Martyrs', and 'Teachers'” Studia Neophilologica 89 (2) (2017), 215-237.

$T O E=$ Roberts, J., and C. Kay with L. Grundy. A Thesaurus of Old English. (Glasgow: University of Glasgow, 2017), http://oldenglishthesaurus.arts.gla.ac.uk/.

Treharne, E. “The Life of English in the Mid-Twelfth Century: Ralph D'Escures's Homily on the Virgin Mary." In Writers of the Reign of Henry II, eds. R. Kennedy and S. Meecham-Jones (New York: Palgrave Macmillan, 2006), 169-186.

Treharne, E. "Making Their Presence Felt: Readers of Ælfric, c.1050-1350." In A Companion to Alfric, eds. H. Magennis and M. Swan (Leiden/Boston: Brill, 20o9), 399-422.

Warner, R. D-N., ed. Early English Homilies from the Twelfth Century Ms. Vesp. D. xiv. Early English Text Society $15^{2}$ (London: Oxford University Press, 1917).

Williams, E. R. “Ælfric’s Grammatical Terminology.” PMLA 73 (5) (1958), 453-462. 


\section{Appendix A: Ælfrician Vocabulary Found in the $D O E$}

This appendix features vocabulary that has been labelled by the $D O E$ as frequently, primarily or exclusively occurring in the works of Ælfric of Eynsham. In addition, the appendix also features lemmata (starting with letters A-I) which have been found in secondary sources on the vocabulary of Ælfric's Grammar (Williams, 1958; Sauer, 2009; Chapman, 2010). As all of these lemmata can be found in the $D O E$, no direct references to these sources are given in Appendix A. The spelling of the lemmata generally follows the $D O E$, but hyphens in compounds have been removed for the purposes of presentation, and in order to save some space. Minor spelling differences between entries in the $D O E$ and their corresponding entries in the Linguistic Linked Data version of TOE (henceforth: TOE) are not mentioned, but major differences are given in the footnotes. The information regarding the frequency of the lemmata in the DOEC and the labels that have been assigned to them have all been copied directly from the entries in the DOE. Whenever there are discrepancies between the $D O E$ and $T O E$, e.g., when one $D O E$ entry corresponds to multiple $T O E$ entries, or vice versa, the relevant entries in this appendix and Appendix B are preceded by an asterisk and feature a footnote explaining the difference. Whenever relevant, these footnotes also mention the new category assigned to the TOE entry or entries (see section 3.1). Entries which could not be tagged in TOE are also preceded by an asterisk. ${ }^{42}$ Plus symbols in this appendix and Appendix B indicate lemmata which are restricted to or frequently occur in the works of Ælfric - either based on my own counts or (in Appendix B) on claims made in prior scholarship - but which have not been labelled by the DOE as such; i.e., they do not have a label featuring the name 'Ælfric' or an Ælfrician text such as 'ÆGram.43

$42 \quad$ See footnotes 33 and 34 .

43 I have also added plus symbols to words labelled 'gram.' (since there is no indication that this label specifically refers to Ælfric's Grammar) and words with the label 'in Gen' (since the book of Genesis was only partially translated by Ælfric). Note that the plus symbols do not necessarily indicate lemmata which would have been labelled by the $D O E$ as Ælfrician (see, e.g., the B2 lemma edlesende which has two occurrences in a non-Ælfrician text, and only one occurrence in the works of Ælfric), but they do indicate lemmata which are restricted to Ælfric in some way, and which cannot be found by searching the $D O E$ for 'ælfric' or a specific Ælfrician text. 


\section{Category A: Lemmata That Only Occur in the Works of Alfric}

Subcategory A1: Lemmata with Frequency in $D O E C \geq 5$

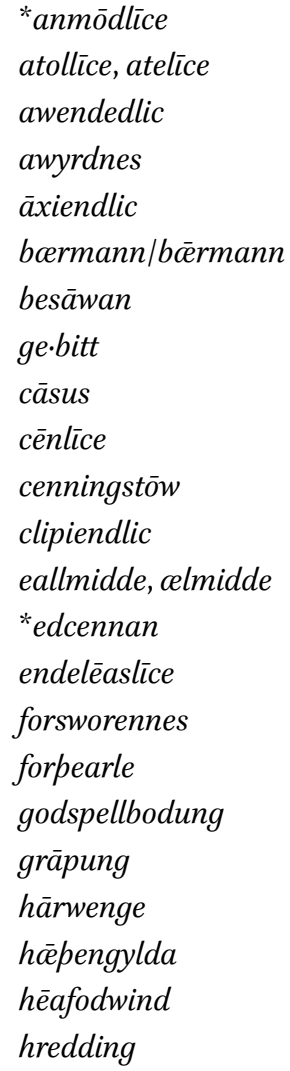

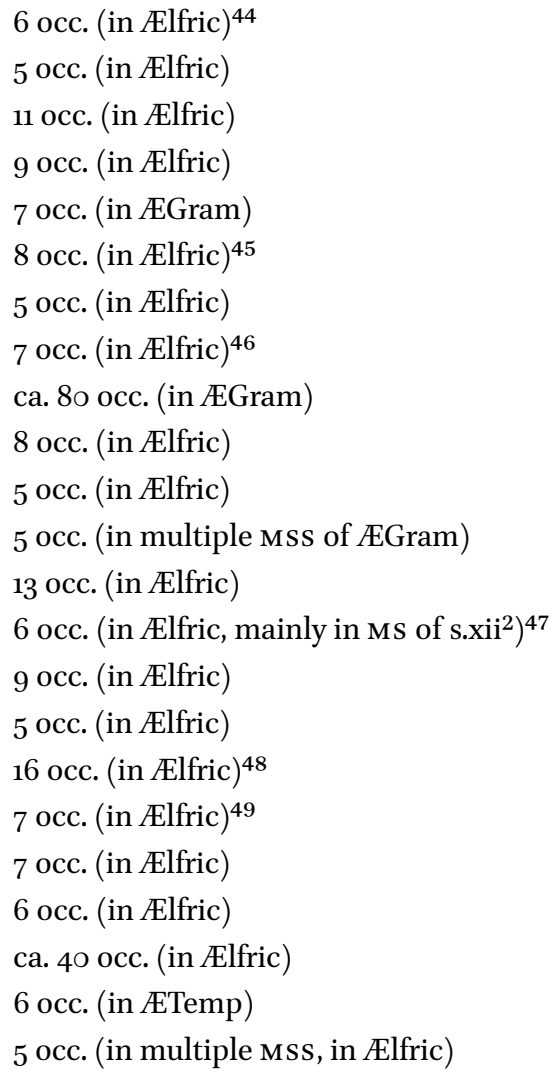

44 This lemma corresponds to the TOE entry ānmōdlīce, which subsumes two DOE entries: anmōdlice (A1) and ānmōdlice (D). For this reason, the entry has been tagged as $\mathrm{D}$ in Evoke. The entry in the $D O E$ (s.v. an-mōdlīce) mentions that "[s]ome of the occurrences given s.v. änmōdlīce 'unanimously' may belong here."

45 The two occurrences in the translation of Joshua (3:2 and 3:14) (DOE, s.v. bcer-mann) have been taken as Ælfrician, based on Kleist (2019: 132-135) (and the citations given there).

46 According to the $D O E$ (s.v. ge.bitt) this noun only seems to occur as part of the collocation "topa gebitt 'gnashing of teeth", and this is the entry which has been tagged in Evoke.

47 According to the $D O E$ (s.v. ed-cennan), this lemma only occurs as a past participle in the collocation "beon edcenned 'to be regenerated, born again' (mainly ref. to rebirth through baptism)". Hence, only the past participle has been taken into account, which corresponds to the TOE entry (ge)edcenned. This entry subsumes two DOE entries: edcennan $(\mathrm{Al})$ and geedcenned (not in appendices) (the verb ge.edcennan constitutes a separate lemma in both the $D O E$ and $T O E$ ). For this reason, the entry has been tagged as D in Evoke.

48 The occurrence in the translation of Judges (3:8) (DOE, s.v. for-pearle) has been taken as Ælfrician, based on Kleist (2019:132-135) (and the citations given there).

49 See also the entry in Appendix B, category A1. 


$\begin{array}{ll}{ }^{*} g e \cdot h \bar{u} & 5 \text { occ. (in Ælfric) })^{50} \\ { }^{*} g e \cdot h \overline{u s l i a n} & 7 \text { occ. (in Ælfric) }{ }^{51}\end{array}$

\section{Subcategory A2: Lemmata with Frequency in $D O E C<5$}

\begin{tabular}{|c|c|}
\hline abropennes & 2 occ. (in multiple MSs, in Ælfric) \\
\hline a-efesian & 1 occ. (in multiple Mss of ÆGram) ${ }^{52}$ \\
\hline $\bar{a}$ fcestlā & 1 occ. (in multiple MSs of ÆGram) \\
\hline āgennes & 2 occ. (in Ælfric) \\
\hline āgenslaga & 4 occ. (mainly in Ælfric) $)^{53}$ \\
\hline *+ägniendlic & 2 occ. $^{54}$ \\
\hline ge.āgniendlic & 4 occ. (in multiple Mss of $Æ G r a m)$ \\
\hline +ahyldendlic & 1 occ. (in multiple mss) \\
\hline +alecgendlic & 1 occ. 55 \\
\hline +alēfednes & 1 occ. \\
\hline +andgytfullic & 2 occ. (in multiple Mss) \\
\hline *andwyrdnes & 3 occ. (in Ælfric) $)^{56}$ \\
\hline arabisc & 4 occ. (in Ælfric) \\
\hline ascrēadian & 1 occ. (in multiple mss of $Æ C H o m)^{57}$ \\
\hline +ascyriendlic & 1 occ. (in multiple Mss) \\
\hline$+a s e \bar{p} a n$ & 1 occ. (in two MSs) \\
\hline +aslaciendlic & 1 occ. (in multiple Mss) \\
\hline+ +etbregdendlic & 1 occ. (in multiple Mss) \\
\hline aetēowiendlic/cetȳwiendlic & 3 occ. (in multiple Mss of $Æ G r a m$ ) \\
\hline
\end{tabular}

$50 \quad$ This lemma could not be found in $T O E$ and has not been tagged.

51 This lemma corresponds to the TOE entry (ge)hüslian, which subsumes three DOE entries: ge.hüslian (A1), hüslian (B1) and ge.hüslod (not in appendices). For this reason, the entry has been tagged as $\mathrm{C} 1$ in Evoke.

$5^{2}$ The hyphen in the entry in this appendix has been retained for clarity.

53 The one occurrence which is not Ælfrician can be found in the thirteenth-century Lambeth Homilies (DOE, s.v. ägen-slaga), but this seems to occur in an Ælfrician quote: "Nan seolf cwale, pet is, azen-sclaza, ne cumeð to godes riche"; cf. Ælfric, De duodecim abusivis: "nan sylfcwala, pæt is agenslaga, ne becymð to Godes rice"; quotes taken from $M E D$ (s.v. äzen-slaza n.) and $D O E$ (s.v. ägen-slaga), respectively. In any case, since the $D O E C$ does not contain the Lambeth Homilies, it would be more accurate to say that this lexeme occurs only three times, all in works by Ælfric.

54 This lemma could not be found in TOE and has not been tagged.

55 Tagged in Evoke as àlecgendlic word.

56 This lemma could not be found in TOE and has not been tagged. The DOE (s.v. andwyrdnes) mentions that these forms may be variants of the Al lemma awyrdnes, and, for this reason, a comment has been added to the entry äwierdnes in Evoke.

Tagged in Evoke as of āscrēadian. 


\begin{tabular}{|c|c|}
\hline$+\bar{e} p r y t$ noun & 2 occ. $^{58}$ \\
\hline ge.bēat & 2 occ. (in Ælfric) \\
\hline bedūfan & 2 occ. (in Ælfric) \\
\hline behegian & 2 occ. (in Ælfric) \\
\hline +behrēowsungtìd & 2 occ. \\
\hline +betwuxalegednes & 1 occ. (in multiple Mss) \\
\hline +betwuxaworpennes & 1 occ. (in multiple Mss) \\
\hline+ ge.bigendlic & 1 occ. (in multiple Mss) \\
\hline bisceopealdor & 4 occ. (in Ælfric) \\
\hline *ge.bōgian & 3 occ. (in Ælfric) $)^{59}$ \\
\hline brces & 4 occ. (in ÆGram and ÆGl) \\
\hline +brcesian, brasian & 1 occ. (in multiple MSs) \\
\hline brocung & 2 occ. (in Ælfric) \\
\hline burhealdor & 4 occ. (in Ælfric) \\
\hline *byrpere ${ }^{1}$ & 3 occ. (in Ælfric) 60 \\
\hline *ge.bytlung & 4 occ. (in Ælfric) ${ }^{61}$ \\
\hline${ }^{*}$ catanenscisc & 2 occ. (in Ælfric) 62 \\
\hline +ge.cīgendlic & 2 occ. (gram.) \\
\hline cliferfēte, cliferfōte & 2 occ. (in multiple Mss, in Ælfric) \\
\hline *cneordlic & 1 occ. (in multiple Mss, in Ælfric) $)^{63}$ \\
\hline${ }^{*}$ ge $\cdot$ cneordlic & 1 occ. (in multiple Mss, in Ælfric) ${ }^{64}$ \\
\hline cnyssung & 2 occ. (in Ælfric) \\
\hline+ crœeftsprāe & 1 occ. \\
\hline cwealmbārnes & 3 occ. (in Ælfric) \\
\hline *cwēmednes & 3 occ. (in Ælfric) 65 \\
\hline +dēelnimendlic & 1 occ. \\
\hline declinian & 3 occ. (in ÆGram) \\
\hline
\end{tabular}

58 Cf. the C1 lexeme èepryt adj., $\bar{x} p r y t e$.

59 This lemma could not be found in TOE and has not been tagged. Cf. the C1 lexeme bogian ${ }^{2}$.

6o This lemma corresponds to the TOE entry (ge)byrpre, which subsumes two DOE entries: byrpere $^{1}(\mathrm{~A} 2)$ and ge.byrpere (not in appendices).

61 This lemma corresponds to the TOE entry (ge)bytlung, which subsumes two DOE entries: ge.bytlung (A2) and bytlung (not in appendices). For this reason, the entry has been tagged as B1 in Evoke.

62 This lemma could not be found in TOE and has not been tagged.

63 This lemma corresponds to the TOE entry (ge)cneordlic, which subsumes two DOE entries: cneordlic (A2) and ge.cneordlic (A2).

64 See footnote for cneordlic (A2).

65 This lemma corresponds to the TOE entry (ge)cwēmednes, which subsumes two DOE entries: cwēmednes (A2) and ge.cwēmednes ( $\mathrm{B1}$ ). For this reason, the entry has been tagged as $\mathrm{B} 1$ in Evoke. 


\begin{tabular}{|c|c|}
\hline +decliniendlic & 3 occ. (gram.) \\
\hline dēofolgylda & 4 occ. (in Ælfric) \\
\hline ge.drēoglēean & 3 occ. (in Ælfric) \\
\hline drēoriglīce & 4 occ. (in Ælfric) \\
\hline *ge.dwimorlice & 3 occ. (in Ælfric) $)^{66}$ \\
\hline *dwolmann & 3 occ. (in Ælfric) 67 \\
\hline eallgōd & 4 occ. (in Ælfric) ${ }^{68}$ \\
\hline *+ge.ēarplcettan & 1 occ. (in multiple Mss) 69 \\
\hline edlesendlic & 4 occ. (in ÆGram) \\
\hline +edlesendlice & 2 occ. \\
\hline +edlesung & 2 occ. (in multiple Mss) \\
\hline efencempa & 3 occ. (in Ælfric) \\
\hline +endelēasnes & 2 occ. (in multiple Mss) \\
\hline eorpfcest & 2 occ. (in multiple MSS of ÆLS) \\
\hline$+\bar{e}$ owiendlic & 1 occ. \\
\hline *ge.ered & 2 occ. (in multiple Mss of $Æ G r a m)^{70}$ \\
\hline *fāgettan & 3 occ. (in multiple Mss of Ælfric) ${ }^{71}$ \\
\hline fāgettung & 1 occ. (in multiple Mss of Ælfric) \\
\hline *fiperhama & 3 occ. (in multiple Mss, in Ælfric) ${ }^{72}$ \\
\hline * +ge.fiperhamod & 2 occ. $^{73}$ \\
\hline
\end{tabular}

66 This lemma corresponds to the TOE entry (ge)dwimorlice, which subsumes two DOE entries: ge.dwimorlīce (A2) and dwimorlice (not in appendices). For this reason, the entry has been tagged as B2 in Evoke. According to the DOE (s.v. ge.dwimorlice), this lexeme only occurs as part of the collocation "gedwimorlice swapeah 'but only as an illusion".

67 See footnote for gedwolman (Appendix B, category D).

68 The $D O E$ (s.v. eall-gōd) notes that "[t]his compound may alternatively be taken as two words" and this is how it appears in TOE.

69 This lemma corresponds to the TOE entry ( ge)êarplcett( $i$ )gan, which subsumes two DOE entries: ge.ēarplcettan (A2) and ēarplcettan, ēarplcettian (Appendix B, category B2). For this reason, the entry has been tagged as B2 in Evoke.

70 This lemma corresponds to the TOE entry (ge)erian, which subsumes three $D O E$ entries: ge.ered (A2), erian (not in appendices) and ge.erian (not in appendices). Since neither of the main verb entries have been labelled as Ælfrician by the $D O E$, but only the past participle ge.ered, the TOE entry has not been tagged in Evoke.

71 This lemma corresponds to three entries in TOE, fägettan (as a verb), fägettan (as an intransitive verb) and fägettan mid wordum, all three of which have been tagged.

72 This lemma corresponds to the TOE entry feperhama, which subsumes two DOE entries: fiperhama (A2) and feperhama (not in appendices). For this reason, the entry has been tagged as D in Evoke.

73 This lemma corresponds to the TOE entry (ge)fiperhamod, which subsumes two DOE entries: ge.fiperhamod (A2) and feperhamode (not in appendices). For this reason, the entry has been tagged as $\mathrm{B}_{2}$ in Evoke. 
foca

+ forbēodendlic

* forbodenlic

+ foresettendlic

*+forgyfendlic,

forgyfenlic

*forscrencend

+ ge.frēdendlic

fremfullic

fyrdlic

gadriendlic

gafolgyldere

glēsing

goldmoestling

* grama ${ }^{2}$

grāpiendlic

*? gyht

* +ha ha interj.

hāsian

* + he he

+healfclipiende
3 occ. (in Ælfric) 74

2 occ. (in multiple Mss)

1 occ. $^{75}$

1 occ. (in multiple Mss)

1 occ. (in multiple Mss) ${ }^{76}$

4 occ. (in multiple MSs of Ælfric) ${ }^{77}$

1 occ. (in multiple Mss) ${ }^{78}$

3 occ. (in Ælfric)

3 occ. (in Ælfric) ${ }^{79}$

1 occ. (in multiple Mss of ÆGram)

3 occ. (in Ælfric)

1 occ. (in multiple Mss of ÆGram)

2 occ. (in multiple Mss of ÆGram and ÆGl)

4 occ. (in Ælfric) 80

3 occ. (in Ælfric, in multiple Mss)

3 occ. (in ÆGram Ms H) ${ }^{81}$

1 occ. ${ }^{82}$

1 occ. (in multiple MSs of ÆGram)

1 occ. $^{83}$

2 occ. (in multiple Mss)

74 The occurrence in the translation of Genesis (18:6) (DOE, s.v. foca) has been taken as Ælfrician, based on Kleist (2019: 132-135) (and the citations given there).

75 This lemma could not be found in TOE and has not been tagged.

76 This lemma corresponds to two entries in TOE, forgifendlic and forgifenlic, but only the first of these has been tagged.

77 This lemma corresponds to two entries for forscrencend in TOE, a noun and an adjective, of which only the noun has been tagged. The $D O E$ (s.v. for-screncend) notes that, in all instances, this lemma is given as "an interpretation of the name Jacob".

78 Tagged in Evoke as gefreedendlic (on).

79 The occurrence in the translation of Joshua (11:10) (DOE, s.v. fyrdlic) has been taken as Ælfrician, based on Kleist (2019: 132-135) (and the citations given there). According to the $D O E$, this lexeme only occurs as part of the collocation "fyrdlic truma 'war-like band".

8o This lemma corresponds to the TOE entry grama, which subsumes two DOE entries: grama $^{1}$ (not in appendices) and $\operatorname{grama}^{2}(\mathrm{~A} 2)$. For this reason, the entry has been tagged as D in Evoke.

81 This lemma corresponds to the TOE entry (ge)gyht, which subsumes two DOE entries:? gyht (A2) and ? ge.gyht, ? ge.gyhte (not in appendices). For this reason, the entry has been tagged as B1 in Evoke.

82 This lemma corresponds to the TOE entry $h a$ ha/he $h \bar{e}$, which subsumes two DOE entries: ha ha interj. (A2) and he he (A2).

83 See footnote for ha ha interj. (A2). 


\begin{tabular}{|c|c|}
\hline *hnāecan & 1 occ. (in multiple MSs of Ælfric) 84 \\
\hline hrcedmōd & 3 occ. (in Ælfric) \\
\hline *ge.hrepian, ge.hreppan & 3 occ. (in multiple Mss, in Ælfric) ${ }^{85}$ \\
\hline$*+h u i(g)$ & 2 occ. (in multiple Mss) ${ }^{86}$ \\
\hline hundseofontigfeald & 2 occ. (in multiple Mss, in Ælfric) \\
\hline hwōnlic & 4 occ. (in Ælfric) \\
\hline
\end{tabular}

\section{Category B: Lemmata That Occur in the Works of Alfric and One Other Text}

Subcategory B1: Lemmata with Frequency in $D O E C \geq 5$

\begin{tabular}{|c|c|}
\hline alēfan, alēfian, alēwan & 25 occ. (mainly in Ælfric) $)^{87}$ \\
\hline andgytlēas & 7 occ. (mainly in Ælfric) \\
\hline *āngenga & 5 occ. (in Beo and in Ælfric) $)^{88}$ \\
\hline 'ge.ānlōecan & 5 occ. (in multiple Mss, mainly in Ælfric) ${ }^{89}$ \\
\hline "ge.ānlōeht & 6 occ. (in Ælfric and in glosses) $)^{90}$ \\
\hline ārwurpfull & 12 occ. (mainly in Ælfric) \\
\hline awendendlic & 12 occ. (mainly in Ælfric, esp. ÆGram) \\
\hline ēfnung & 25 occ. (mainly in Ælfric) $)^{91}$ \\
\hline änlīce & 9 occ. (in Ælfric and the gloss of Ælfric's Colloquy) \\
\hline +bebēodendlic & 5 occ. (in multiple Mss) \\
\hline decian & 6 occ. $(5 \times$ in Ælfric, $4 \times$ in the same homily $)$ \\
\hline riwen & 6 occ. (in homilies, mainly in Ælfric) \\
\hline bestreowian/bestrēowian & 9 occ. (mainly in Ælfric) \\
\hline bïgednes/ge.bïgendnes/ & 10 occ. (in multiple Mss, mainly in ÆGram) \\
\hline
\end{tabular}

84 This lemma corresponds to the TOE entry (ge)hnēcan, which subsumes two DOE entries: hnēcan (A2) and ge.hnēecan (not in appendices). For this reason, the entry has been tagged as B2 in Evoke (the occurrences listed under DOE (s.v. ge.hncecan, sense 1) have not been taken into account, since they correspond to the sense associated with the TOE entry gehnēcan).

85 See footnote for hrepian, hreppan (D). See also the entry in Appendix B, category E1.

86 This lemma could not be found in $T O E$ and has not been tagged.

87 See also the entry in Appendix B, category B1.

88 This lemma corresponds to two entries for āngenga in $T O E$, a noun and an adjective, which have both been tagged.

89 This lemma corresponds to the TOE entries geānlēecan and (ge)ānlēecan. The first of these entries subsumes the DOE entries ge.ānlēecan $(\mathrm{B} 1)$ and ge.ānlēeht $(\mathrm{B} 1)$; the second TOE entry subsumes the same two $D O E$ lemmata, in addition to ânlēean (not in appendices). Both TOE entries have been tagged as $\mathrm{C} 1$ in Evoke.

90 See footnote for ge. ānlēecan (B1).

91 The three occurrences in the translations of Genesis (8:11, 15:12) and Joshua (2:5) (DOE, s.v. äfnung) have been taken as Ælfrician, based on Kleist (2019: 132-135) (and the citations given there). 


\begin{tabular}{|c|c|}
\hline blysa/blȳsa, blyse/blȳse & 5 occ. (mainly in Ælfric) \\
\hline bysmorfull & 26 occ. (mainly in Ælfric) $)^{92}$ \\
\hline *ge.cwēmednes & 10 occ. (mainly in Ælfric) $)^{93}$ \\
\hline dēedlic & 16 occ. (mainly in ÆGram) \\
\hline +declinung & ca. 6 o occ. (gram.) \\
\hline *+diptongon & 6 occ. (in multiple mss) ${ }^{94}$ \\
\hline *dwollice & 20 occ. (all but $1 \times$ in Ælfric) ${ }^{95}$ \\
\hline dydrung & 17 occ. (all but $1 \times$ in Ælfric) \\
\hline eallnīwe & 8 occ. (mainly in Ælfric) $)^{96}$ \\
\hline eargian & 9 occ. (in Wulfstan and Ælfric) \\
\hline *edcwician, edcucian & 14 occ. (mainly in Ælfric) ${ }^{97}$ \\
\hline efentwā, emntwā & 6 occ. (mainly in Ælfric) $)^{98}$ \\
\hline ess & 8 occ. (mainly in ÆGram) \\
\hline fenlic & 6 occ. (mainly in Ælfric) \\
\hline fiperrica & 6 occ. (in multiple Mss, mainly in Ælfric) \\
\hline gefflēschamod & 8 occ. (mainly in Ælfric) $)^{99}$ \\
\hline flèring & 11 occ. (mainly in Ælfric) ${ }^{100}$ \\
\hline
\end{tabular}

92 The occurrence in the translation of Genesis (19:3) (DOE, s.v. bysmor-full) has been taken as Ælfrician, based on Kleist (2019:132-135) (and the citations given there).

93 See footnote for cwēmednes (A2). According to the DOE (s.v. ge.cwèmednes), this noun only occurs in the works of Ælfric as part of the collocation "to gecwemednesse (with dat. of person) 'to the satisfaction (of someone)". Cf. the A2 lexeme cwèmednes, which also only occurs as part of this collocation (and note that two of its instances occur where another manuscript has a form of ge.cwèmednes).

94 This lemma could not be found in TOE and has not been tagged.

95 This lemma corresponds to the TOE entry ( $g e$ )dwollice, which subsumes two DOE entries: dwollice $(\mathrm{B} 1)$ and ge.dwollice (not in appendices). For this reason, the entry has been tagged as $\mathrm{C} 1$ in Evoke.

96 The occurrence in the translation of Judges (16:11) (DOE, s.v. eall-niwe) has been taken as Ælfrician, based on Kleist (2019: 132-135) (and the citations given there).

97 This lemma corresponds to the TOE entry (ge)edcwician, which subsumes two DOE entries: edcwician, edcucian ( $\mathrm{B} 1$ ) and geedcwician, geedcucian ( $\mathrm{C} 1)$. For this reason, the entry has been tagged as $\mathrm{C} 1$ in Evoke. Cf. the D lexeme ge.edcwicod, ge.edcucod.

98 According to the $D O E$ (s.v. efen-twā, emn-twā) this lemma is only attested as part of the prepositional phrase "on emtwa 'in/into two equal parts" and this is the entry which has been tagged in Evoke (on efentwā).

99 The occurrence in the Mcesse creda (DOEC short title: 'Lit 3.2 (Thorpe)', Cameron number: 'B12.3.2') (DOE, s.v. ge.fläsc-hamod) has been taken as Ælfrician, based on Kleist (2019: 193).

100 The occurrence in the translation of Genesis (6:16) (DOE, s.v. flèring) has been taken as Ælfrician, based on Kleist (2019: 132-135) (and the citations given there). 


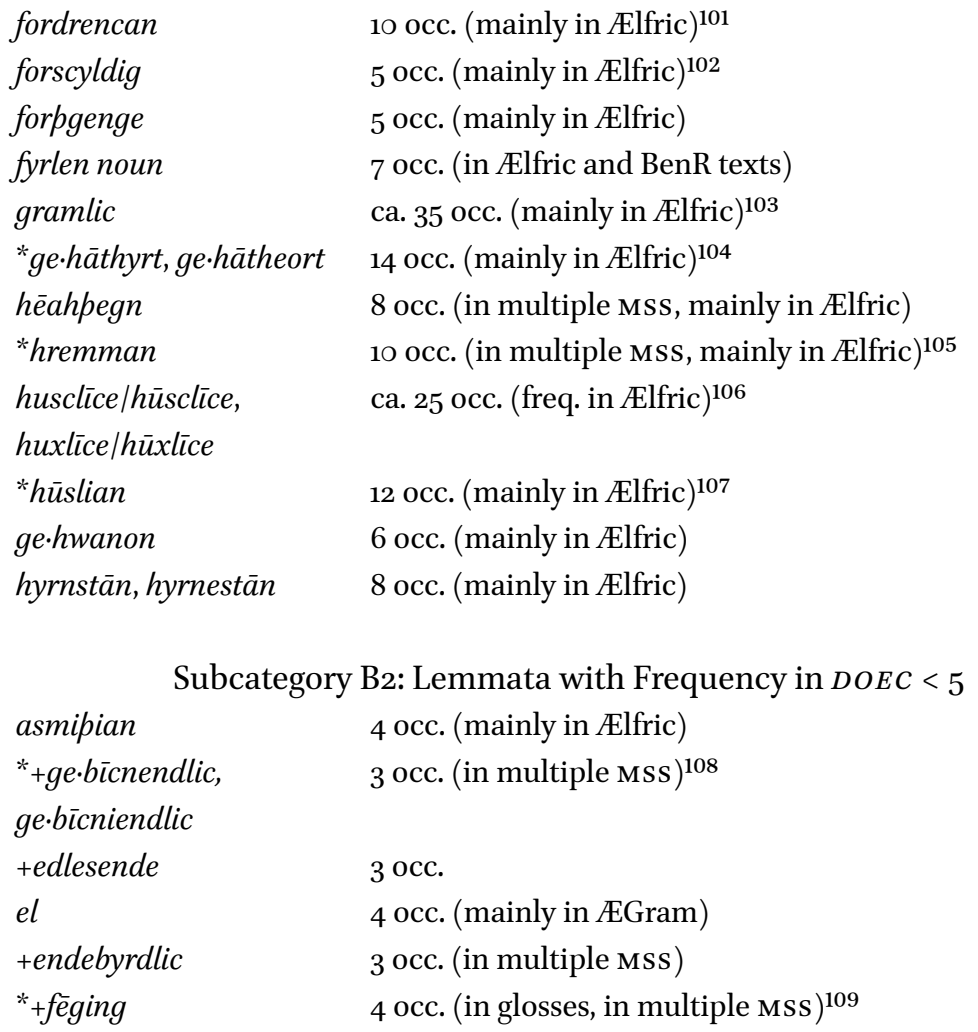

101 The three occurrences in the translation of Genesis (19:32, 19:33 and 19:35) (DOE, s.v. fordrencan) have been taken as Ælfrician, based on Kleist (2019: 132-135) (and the citations given there).

102 The occurrence in the translation of Genesis (19:15) (DOE, s.v. for-scyldig) has been taken as Ælfrician, based on Kleist (2019:132-135) (and the citations given there).

103 The occurrence in the translation of Judges (4:2) (DOE, s.v. gramlic) has been taken as Ælfrician, based on Kleist (2019:132-135) (and the citations given there). See also the entry in Appendix B, category B1.

104 This lemma corresponds to two entries in TOE, gehäthiert and (ge)hätheort, but only the first of these has been tagged.

105 This lemma corresponds to the TOE entry (ge)hremman, which subsumes three DOE entries: hremman (B1), ge.hremman (not in appendices) and ge.hremmed (not in appendices). For this reason, the entry has been tagged as D in Evoke.

106 The occurrence in the translation of Judges (5:11) (DOE, s.v. husclīce, huxlīce) has been taken as Ælfrician, based on Kleist (2019: 132-135) (and the citations given there).

107 See footnote for ge.hüslian $(\mathrm{Ar})$.

108 This lemma corresponds to the TOE entry (ge)bicn(ig)endlic. However, since the sense associated with this entry does not correspond to the sense in which Ælfric uses this lemma, the entry has not been tagged in Evoke.

109 This lemma corresponds to the TOE entry ( $g$ e)féging, which subsumes two DOE entries: féging (B2) and ge.féging (B2). For this reason, the entry has been tagged as $\mathrm{C}_{1}$ in Evoke. 


\begin{tabular}{|c|c|}
\hline * +ge.fêging & 3 occ. (in glosses) $)^{110}$ \\
\hline+ forpriht & 2 occ. (in multiple Mss) \\
\hline +ge.fyllendlic & 2 occ. (in multiple Mss) \\
\hline +geornfullic & 4 occ. (in multiple mss) \\
\hline hordian & 4 occ. (mainly in Ælfric) \\
\hline +hundnigontigwintre & 4 occ. (in Gen) $)^{111}$ \\
\hline +hundwintre & 4 occ. (in Gen) $)^{112}$ \\
\hline
\end{tabular}

Category C: Lemmata That Occur in the Works of Alfric and between Two and Four Other Texts

Subcategory C1: Lemmata with Frequency in $D O E C \geq 5$

\begin{tabular}{|c|c|c|}
\hline * $a$ & ca. 90 occ. (mainly in ÆGram) & {$[\text { in } 4 \text { other texts] }]^{113}$} \\
\hline acumendlic & $\begin{array}{l}5 \text { occ. (in multiple Mss, } \\
\text { mainly in Ælfric) }\end{array}$ & [in 2 other texts] \\
\hline ancorsetla & 7 occ. (mainly in Ælfric) & [in 2 other texts] \\
\hline$\overline{a e} b r \bar{e} c e, \bar{e} b r y c e$ & 10 occ. (mainly in Ælfric) & [in 2 other texts] \\
\hline cetslìdan & 9 occ. (mainly in Ælfric) & [in 2 other texts] \\
\hline $\bar{\alpha} p r y t$ adj., $\bar{e} p r y t e$ & 7 occ. (freq. in Ælfric) & {$[\text { in } 2 \text { other texts }]^{114}$} \\
\hline *babilonisc & 13 occ. (mainly in Ælfric) & {$[\text { in } 2 \text { other texts] }]^{115}$} \\
\hline basing & 16 occ. (freq. in Ælfric) & {$[\text { in } 2 \text { other texts }]^{116}$} \\
\hline +bcecestre & 14 occ. (freq. in Gen) & {$[\text { in } 4 \text { other texts] }]^{117}$} \\
\hline becēapian & 21 occ. (mainly in Ælfric) & [in 4 other texts] \\
\hline
\end{tabular}

110 See footnote for féging $(\mathrm{B} 2)$.

111 Two occurrences in the translation of Genesis (5:9 and 5:17) (DOE, s.v. hundnigontigwintre) have not been taken as Ælfrician, while two other occurrences in the translation of Genesis (17:1 and 17:17) have been taken as Ælfrician, based on Kleist (2019: 132-135) (and the citations given there).

112 Two occurrences in the translation of Genesis (5:6 and 5:18) (DOE, s.v. hund-wintre) have not been taken as Ælfrician, while two other occurrences in the translation of Genesis (17:17 and 21:5) have been taken as Ælfrician, based on Kleist (2019: 132-135) (and the citations given there).

113 This lemma could not be found in $T O E$ and has not been tagged.

114 According to the $D O E$ (s.v. $\bar{a}-p r y t$ adj., $\bar{e}-p r y t e$ ), "the instances without final -e may conceivably belong to ëpryt noun, q.v.". Cf. the A2 lexeme ēpryt noun.

115 This lemma could not be found in TOE and has not been tagged.

116 The occurrence in the translation of Joshua (7:21) (DOE, s.v. basing) has been taken as Ælfrician, based on Kleist (2019: 132-135) (and the citations given there).

117 The nine occurrences in the translation of Genesis (4O:1, 4O:2, 40:16, 40:20 and 41:9) (DOE, s.v. bcecestre) have not been taken as Ælfrician, based on Kleist (2019: 132-135) (and the citations given there). 


\begin{tabular}{|c|c|c|}
\hline *beddrida & ca. 35 occ. (mainly in Ælfric) & {$[\text { in } 2 \text { other texts] }]^{118}$} \\
\hline *bedydrian & 18 occ. (mainly in Ælfric) & [in 3 other texts $]^{119}$ \\
\hline *bōgian ${ }^{2}$ & 10 occ. (freq. in Ælfric) & {$[\text { in } 3 \text { other texts }]^{120}$} \\
\hline brȳdbedd & 10 occ. (mainly in Ælfric) & [in 2 other texts] \\
\hline burhscīr & 21 occ. (mainly in Ælfric) & {$[\text { in } 3 \text { other texts }]^{121}$} \\
\hline *ge.bysgian & 13 occ. (mainly in Ælfric) & {$[\text { in } 3 \text { other texts }]^{122}$} \\
\hline *ge.bȳsnian & 20 occ. (mainly in Ælfric) & {$[\text { in } 3 \text { other texts }]^{123}$} \\
\hline *ceorlian & 17 occ. (freq. in Ælfric) & {$[\text { in } 4 \text { other texts }]^{124}$} \\
\hline *+clȳsing, clȳsung & 20 occ. & {$[\text { in } 4 \text { other texts }]^{125}$} \\
\hline cwealmbc̄ere, cwylmbc̄ere & 29 occ. (mainly in Ælfric) & [in 2 other texts] \\
\hline cystiglīce & 7 occ. (freq. in Ælfric) & [in 2 other texts] \\
\hline dēadlicnes & $\begin{array}{l}10 \text { occ. (mainly in Ælfric } \\
\text { and Bede) }\end{array}$ & [in 2 other texts] \\
\hline dēofollice & $\begin{array}{l}11 \text { occ. (in homilies, } \\
\text { mainly in Ælfric) }\end{array}$ & [in 2 other texts] \\
\hline drȳmann & $\begin{array}{l}\text { ca. } 45 \text { occ. (in homilies, } \\
\text { freq. in Ælfric) }\end{array}$ & [in 3 other texts] \\
\hline *dwollic & 18 occ. (all but $3 \times$ in Ælfric) & [in 2 other texts] $]^{126}$ \\
\hline
\end{tabular}

118 This lemma corresponds to two entries for bedreda in TOE, a noun and an adjective, of which only the adjective has been tagged.

119 This lemma corresponds to two entries in TOE, bedydrian and bedydrian ... wip, which have both been tagged. The occurrence in the translation of Genesis (44:15) (DOE, s.v. bedydrian) has not been taken as Ælfrician, based on Kleist (2019:132-135) (and the citations given there).

120 This lemma could not be found in $T O E$ and has not been tagged. The occurrence in the translation of Genesis (21:34) (DOE, s.v. boggian ${ }^{2}$ ) has been taken as Ælfrician, based on Kleist (2019:132-135) (and the citations given there). Cf. the A2 lexeme ge.bogian.

121 The occurrence in the translation of Joshua (14:2) (DOE, s.v. burh-scir) has been taken as Ælfrician, based on Kleist (2019: 132-135) (and the citations given there).

122 This lemma corresponds to the TOE entry (ge)bisgian, which subsumes three DOE entries: ge.bysgian ( $\mathrm{C1})$, bysgian (not in appendices) and ge.bysgod (not in appendices). For this reason, the entry has been tagged as D in Evoke.

123 This lemma corresponds to two entries in TOE, (ge)bȳsnian and (ge)bisenian, which have both been tagged. Both TOE entries subsume three DOE entries: ge.bȳsnian (C1), bȳsnian (not in appendices) and ge.bȳsnod (not in appendices). For this reason, the TOE entries have been tagged as D in Evoke.

124 This lemma corresponds to the TOE entry (ge)ceorlian, which subsumes two DOE entries: ceorlian $(\mathrm{C} 1)$ and ge.ceorlian (not in appendices).

125 This lemma corresponds to two entries in TOE, clȳsing and clȳsung, but only the second of these has been tagged.

126 This lemma corresponds to the TOE entry (ge)dwollic, which subsumes two DOE entries: dwollic $(\mathrm{C} 1)$ and ge.dwollic (not in appendices). The occurrence in the translation of Judges (15:24) (DOE, s.v. dwollic) has been taken as Ælfrician, based on Kleist (2019: 132-135) 


\begin{tabular}{|c|c|c|}
\hline *e & ca. 40 occ. $(38 \times$ in $Æ G r a m)$ & {$\left[\right.$ in 3 other texts] ${ }^{127}$} \\
\hline ealdorbisceop & 20 occ. (mainly in Ælfric) & [in 3 other texts] \\
\hline eallwealdend, & 13 occ. (freq. in Ælfric) & [in 4 other texts] \\
\hline \multicolumn{3}{|l|}{ celwealdend } \\
\hline eallwealdende & 12 occ. (freq. in Ælfric) & [in 4 other texts] \\
\hline ge.edcwician, & 19 occ. (mainly in Ælfric) & [in 2 other texts] $]^{128}$ \\
\hline \multicolumn{3}{|l|}{ ge.edcucian } \\
\hline *ge.efenlōecing, & 9 occ. (freq. in Ælfric) & [in 2 other texts] ${ }^{129}$ \\
\hline \multicolumn{3}{|l|}{ ge.efenlēeung } \\
\hline *ge.egesian, & 11 occ. (freq. in Ælfric) & [in 2 other texts] ${ }^{130}$ \\
\hline \multicolumn{3}{|l|}{ ge.egsian } \\
\hline *elpēodiglīce & 8 occ. (mainly in ÆGram) & {$[\text { in } 2 \text { other texts] }]^{131}$} \\
\hline fantwceter & 10 occ. (mainly in Ælfric) & [in 2 other texts] \\
\hline ge.fègednes & 11 occ. (mainly in glosses, & [in 2 other texts] \\
\hline & esp. ÆGram) & \\
\hline fläsclicnes & 9 occ. (freq. in Ælfric) & [in 2 other texts] \\
\hline flocc & 21 occ. (freq. in Ælfric) & {$[\text { in } 4 \text { other texts] }]^{132}$} \\
\hline
\end{tabular}

(and the citations given there). Consequently, I take there to be only two non-Ælfrician occurrences, not three, as the $D O E$ notes in the entry to this lemma.

127 This lemma could not be found in $T O E$ and has not been tagged.

128 This lemma simply corresponds to the TOE entry geedcwician. See also the footnote for edcwician, edcucian (B1). Cf. the D lexeme ge.edcwicod, ge.edcucod.

129 This lemma corresponds to the TOE entry (ge)efenlēecung, which subsumes two DOE entries: ge.efenläeing, ge.efenlāecung $(\mathrm{C} 1)$ and efenlēecing, efenläcung (not in appendices). For this reason, the entry has been tagged as D in Evoke.

130 This lemma corresponds to the TOE entry (ge)egesian, which subsumes three DOE entries: ge.egesian, ge.egsian ( $\mathrm{C1}$ ), egesian, egsian (not in appendices) and ge.egesod, ge.egsod (not in appendices). For this reason, the entry has been tagged as D in Evoke. The occurrence in the translation of Judges (7:22) (DOE, s.v. ge.egesian, ge.egsian) has been taken as Ælfrician, based on Kleist (2019: 132-135) (and the citations given there).

131 This lemma corresponds to the TOE entry elpeod(ig)lice, which subsumes two DOE entries: elpēodiglīce ( $\left.\mathrm{C}_{1}\right)$ and elpēodlīce (not in appendices).

132 The four occurrences in the translation of Genesis (32:8, 32:10 and 33:8) (DOE, s.v. flocc) have not been taken as Ælfrician, while the occurrence in the translation of Joshua (8:10) has been taken as Ælfrician, based on Kleist (2019:132-135) (and the citations given there). According to the $D O E$, the form 'floccum' occurs in manuscript $\mathrm{P}$ of Ælfric's translation of Judges, while manuscript $\mathrm{Z}$ has 'folcum'. If 'folcum' is the original Ælfrician reading, this lemma should be moved to category D. However, the $D O E$ (s.v. folc, sense 13) does point out that the two instances of folc with the sense "band of men, company, division of an army" (one of which occurs in the quotation found in Judges, and the other in the D manuscript of the Anglo-Saxon Chronicle) were "perhaps intended for flocc q.v.", which would argue in favour of 'floccum' being the more plausible, and, therefore, more authorial, reading of the two. 


\begin{tabular}{|c|c|c|}
\hline flotmann & $\begin{array}{l}15 \text { occ. (mainly in } \\
\text { Ælfric and in glosses) }\end{array}$ & [in 3 other texts] \\
\hline forhrape & 11 occ. (mainly in Ælfric) & {$[\text { in } 3 \text { other texts }]^{133}$} \\
\hline fōrmete & 8 occ. (mainly in Ælfric) & {$[\text { in } 3 \text { other texts] }]^{134}$} \\
\hline formolsnian & 10 occ. (mainly in Ælfric) & [in 2 other texts] \\
\hline forpēeran & 14 occ. (mainly in Ælfric) & [in 3 other texts] \\
\hline forrotodnes & 15 occ. (freq. in Ælfric) & [in 4 other texts] \\
\hline forsecgan & 20 occ. (freq. in Ælfric) & [in 4 other texts] \\
\hline fracopnes & 11 occ. (freq. in Ælfric) & [in 4 other texts] \\
\hline frumsceapen & 28 occ. (freq. in Ælfric) & [in 4 other texts] \\
\hline frumwcestm & 10 occ. (freq. in Ælfric) & [in 2 other texts] \\
\hline fugelcynn & 29 occ. (freq. in Ælfric) & [in 4 other texts] $]^{135}$ \\
\hline *fyrnlic & 15 occ. (mainly in Ælfric) & {$[\text { in } 2 \text { other texts] }]^{136}$} \\
\hline fyrwitnes & $\begin{array}{l}9 \text { occ. (in multiple MSs, } \\
\text { mainly in Ælfric) }\end{array}$ & [in 2 other texts] \\
\hline hengen & 24 occ. (mainly in Ælfric) & [in 3 other texts] \\
\hline hlȳwp, hlēowp & 11 occ. (freq. in Ælfric) & [in 4 other texts] \\
\hline hrepung & ca. 35 occ. (mainly in Ælfric) & [in 4 other texts] \\
\hline +hungorgēar & 9 occ. (mainly in Gen) & [in 2 other texts] $]^{137}$ \\
\hline $\begin{array}{l}\text { husclic/hüsclic, } \\
\text { huxlic/hüxlic }\end{array}$ & 11 occ. (mainly in Ælfric) & {$[\text { in } 2 \text { other texts] }]^{138}$} \\
\hline $\begin{array}{l}\text { hwearftlian, } \\
\text { hwyrftlian }\end{array}$ & $\begin{array}{l}7 \text { occ. (in multiple MSs, } \\
\text { in Ælfric and glosses) }\end{array}$ & [in 2 other texts] \\
\hline
\end{tabular}

133 The occurrence in the translation of Genesis (2O:7) (DOE, s.v.for-hrape) has been taken as Ælfrician, based on Kleist (2019: 132-135) (and the citations given there).

134 The two occurrences in the translation of Genesis (42:25 and 45:21) (DOE, s.v. fōr-mete) have not been taken as Ælfrician, based on Kleist (2019: 132-135) (and the citations given there).

135 The three occurrences in the translation of Genesis (1:30, 7:3 and 7:8) (DOE s.v. fugelcynn) have been taken as Ælfrician, based on Kleist (2019: 132-135) (and the citations given there).

136 This lemma could not be found in TOE and has not been tagged. The DOE (s.v. fyrnlic) notes that some citations may also be seen as instances of the lemma firenlic, rather than fyrnlic (but firenlic has not been tagged in Evoke).

137 Six occurrences in the translation of Genesis (41:27, 41:36, 41:50, 41:53 and 45:11) (DOE, s.v. hungor-gēar) have not been taken as Ælfrician, while one other occurrence in the translation of Genesis (12:10) has been taken as Ælfrician, based on Kleist (2019:132-135) (and the citations given there).

138 The occurrence in the Letter to Brother Edward (DOEC short title: 'Let 2 (Clayton)', Cameron number: 'B6.2') (DOE, s.v. husclic, huxlic) has been taken as Ælfrician, based on Kleist (2019: 156-157) (and the citations given there). 
hwïlwendlīce,

hwïlendlīce

*hȳra ${ }^{2}$
7 occ. (mainly in Ælfric)

14 occ. (mainly in ÆCHom I, 17) [in 3 other texts] $]^{139}$

\section{Subcategory C2: Lemmata with Frequency in $D O E C<5$}

None

Category D: Widely Used Lemmata, Found in Five or More Other Texts, Frequently Found in the Works of Elfric

abitan

*ablāwan

ablycgan

*abūgan

acennednes

acwician, acucian

*adrēefan

adȳdan

afindan

aflȳgan, aflȳan

*afyllan ${ }^{1}$

afyrhtan

*ahreddan

*anbidian, andbidian

andsc̄te ca. 65 occ. (freq. in Ælfric)

29 occ. (freq. in Ælfric) ${ }^{140}$

ca. 3 o occ. (mainly in Ælfric)

ca. 100 occ. (freq. in Ælfric) ${ }^{141}$

ca. 175 occ. (freq. in Ælfric)

20 occ. (freq. in Ælfric)

ca. 250 occ. (freq. in Ælfric) ${ }^{142}$

ca. 5 o occ. (mainly in Ælfric)

ca. 8o occ. (freq. in Ælfric)

ca. 100 occ. (freq. in Ælfric)

ca. 200 occ. (freq. in Ælfric) ${ }^{143}$

ca. 175 occ. (freq. in Ælfric)

ca. 175 occ. (freq. in Ælfric) 144

ca. 175 occ. (freq. in Ælfric and psalter/canticle glosses; $1 \times$ in poetry in Beo, see sense 1.a.ii $)^{145}$

ca. 35 occ. (freq. in Ælfric)

139 This lemma corresponds to the TOE entry hỹra, which subsumes two DOE entries: hỹra ${ }^{1}$ (not in appendices) and $h \bar{y} r a^{2}(\mathrm{C} 1)$. For this reason, the entry has been tagged as D in Evoke.

140 This lemma corresponds to four entries in TOE, āblāwan, ūp āblāwan, üt āblāwan and äblāwan on/ofer, all four of which have been tagged.

141 This lemma corresponds to four entries in TOE, ābūgan, ābügan fram, ābūgan (tō) and $\bar{a} b \bar{g}$ gan ( fram), of which only ābügan fram has not been tagged.

142 This lemma corresponds to two entries in TOE, ädräefan and $\bar{u} t \bar{a} d r \bar{e} f a n$, which have both been tagged.

143 This lemma corresponds to the TOE entry äfyllan, which subsumes two DOE entries: afyllan $^{1}(\mathrm{D})$ and afyllan ${ }^{2}$ (not in appendices).

144 This lemma corresponds to two entries in TOE, ähreddan wip/fram and ähreddan (cet/on) fram), which have both been tagged.

145 This lemma corresponds to the TOE entry (ge)anbidian, which subsumes three DOE entries: anbidian, andbidian (D), ge.anbidian, ge.andbidian (not in appendices) and ge.anbidod (not in appendices). 


\begin{tabular}{|c|c|}
\hline *andwyrdan & ca. 6 oo occ. (freq. in Ælfric) ${ }^{146}$ \\
\hline ge.angsumian & ca. 35 occ. (mainly in Ælfric) \\
\hline *ānmōdlīce & ca. 6 o occ. (freq. in Ælfric) ${ }^{147}$ \\
\hline ānrc̄ede, ānrc̄ed & ca. 100 occ. (freq. in Ælfric) ${ }^{148}$ \\
\hline ānrc̄ednes & ca. 70 occ. (freq. in Ælfric) \\
\hline *ansund & ca. 100 occ. (freq. in Ælfric) $)^{149}$ \\
\hline antimber & ca. 45 occ. (freq. in Ælfric) \\
\hline *anweald & $\begin{array}{l}\text { ca. } 1100 \text { occ. (freq. in Alfredian translations } \\
\text { and Ælfric; Wulfstan prefers geweald) }{ }^{150}\end{array}$ \\
\hline arodlīce, ardlīce & ca. 85 occ. (mainly in Ælfric) \\
\hline asolcennes & ca. 35 occ. (freq. in Ælfric) \\
\hline aspendan & ca. 5 o occ. (freq. in Ælfric) \\
\hline atēoriendlic & 28 occ. (mainly in Ælfric) \\
\hline awèdan & ca. 35 occ. (freq. in Ælfric) \\
\hline awendan & ca. 700 occ. (freq. in Ælfric) \\
\hline *awreccan & ca. 55 occ. (freq. in Ælfric) $)^{151}$ \\
\hline èlic & $\begin{array}{l}\text { ca. } 40 \text { occ. (mainly in Ælfric and in glosses } \\
\text { to Aldhelm) }\end{array}$ \\
\hline cetflēon & 28 occ. (freq. in Ælfric) \\
\hline *cetforan adv. and prep. & ca. 500 occ. (freq. in Ælfric) ${ }^{152}$ \\
\hline cetwindan & ca. 6o occ. (freq. in Ælfric) \\
\hline cepelboren & ca. 70 occ. (freq. in Ælfric, none in poetry) \\
\hline
\end{tabular}

146 This lemma corresponds to the $T O E$ entry ( $g e$ )andwyrdan, which subsumes three $D O E$ entries: andwyrdan (D), ge.andwyrdan (not in appendices) and ge.andwyrd (not in appendices). See also the entry in Appendix B, category E1.

147 See footnote for anmōdlìce (A1). The $D O E$ (s.v. ān-mōdlīce) mentions that "[s]ome of the occurrences given s.v. anmōdlīce 'resolutely' may belong here."

148 See also the entry in Appendix B, category D.

149 This lemma corresponds to two entries for ansund in TOE, a noun and an adjective, which have both been tagged; the only sense associated with the noun is 'healthy', an adjective, which means that this TOE entry has most likely received an incorrect part of speech label.

150 This lemma corresponds to two entries in TOE, anweald and onweald, but only the second of these has been tagged. Two multiword entries in TOE which feature this noun, in anweald gereccan and anweald/(ge)weald agan, have not been tagged. The DOE (s.v. anweald) mentions that "[s]ome of the occurrences spelled an- and given here may belong to ānweald, especially when the word refers to God's sole power or to an earthly ruler's absolute (or tyrannous) sway."

151 This lemma corresponds to two entries for āwreccan in TOE, a verb and a specifically transitive verb, which have both been tagged.

$15^{2}$ This lemma corresponds to two entries for cetforan in TOE, a preposition and an adverb, which have both been tagged. See also the entry in Appendix B, category F. 


\begin{tabular}{|c|c|}
\hline cepelborennes & ca. 25 occ. (mainly in Ælfric) \\
\hline bemǣenan & ca. 35 occ. (freq. in Ælfric) \\
\hline ge.bēor & 25 occ. (mainly in Ælfric) \\
\hline berȳpan & $\begin{array}{l}26 \text { occ. (disproportionately freq. in Ælfric } \\
\text { and Wulfstan) }\end{array}$ \\
\hline *besārgian & ca. 50 occ. (freq. in Ælfric) $)^{153}$ \\
\hline beswingan & ca. 65 occ. (freq. in Ælfric) \\
\hline *bibliopēce, biblipēca & 23 occ. (mainly in Ælfric) ${ }^{154}$ \\
\hline bigleofa & ca. 175 occ. (freq. in Ælfric) \\
\hline *bōclic & ca. $5^{\circ}$ occ. (freq. in Ælfric) $)^{155}$ \\
\hline bodung & ca. 175 occ. (freq. in Ælfric and glosses) \\
\hline brāep & ca. 5 o occ. (freq. in Ælfric) \\
\hline *ge.bȳsnung & ca. 5 O occ. (mainly in Ælfric) $)^{156}$ \\
\hline ge.bytlu & 30 occ. (mainly in Ælfric, $9 \times$ in ÆLS [Thomas]) \\
\hline campdōm & 27 occ. (freq. in Ælfric) \\
\hline $\begin{array}{l}\text { *ceasterge.wara, } \\
\text { ceasterge.waru }\end{array}$ & ca. 6 o occ. (freq. in Ælfric) $)^{157}$ \\
\hline ceorian, cyrian & ca. 45 occ. (freq. in Ælfric) \\
\hline *cēpan & ca. 100 occ. (freq. in Ælfric) ${ }^{158}$ \\
\hline *ge.cneordnes & ca. 55 occ. (freq. in Ælfric) ${ }^{159}$ \\
\hline cwellere & ca. 150 occ. (mainly in Ælfric) \\
\hline cyre & ca. 6o occ. (disproportionately freq. in Ælfric) \\
\hline cystignes & 26 occ. (freq. in Ælfric) \\
\hline dcegperlic & ca. 30 occ. (freq. in Ælfric) \\
\hline dēofollic & ca. 125 occ. (in prose and glosses; freq. in Ælfric) \\
\hline
\end{tabular}

153 This lemma corresponds to two entries in TOE, besārgian and besārgian (be/for), which have both been tagged.

154 This lemma corresponds to two entries in TOE, bibliopēce and bibliopēca, which have both been tagged. The DOE (s.v. bibliopēce, biblipēca) notes that Ælfric uses this noun in its second sense: "in Ælfric, specifically: the Scriptures in Jerome's canon".

155 This lemma corresponds to two entries in TOE, böclic and böclic stcef, which have both been tagged.

156 This lemma could not be found in TOE and has not been tagged.

157 This lemma could not be found in $T O E$ and has not been tagged.

${ }_{15} 8$ This lemma corresponds to two entries in TOE, cēpan and (ge)cēpan, which have both been tagged. The second of these entries subsumes the DOE entries cēpan (D) and ge.cēpan (not in appendices).

159 This lemma corresponds to two entries in TOE, gecneordnes and (ge)cneordnes, which have both been tagged. The second of these entries subsumes the DOE entries ge.cneordnes (D) and cneordnes (not in appendices). 


\begin{tabular}{|c|c|}
\hline deriendlic & $\begin{array}{l}\text { ca. } 6 \text { o occ. (esp. freq. in Ælfric }\left[25^{\times}\right] \\
\text {and HyGl }[18 \times])^{160}\end{array}$ \\
\hline *diht & ca. 100 occ. (disproportionately freq. in Ælfric) ${ }^{161}$ \\
\hline *dry & ca. 9o occ. (disproportionately freq. in Ælfric) $)^{162}$ \\
\hline drȳcrceft & ca. 100 occ. (disproportionately freq. in Ælfric) \\
\hline *dyrstelice & 21 occ. (freq. in Ælfric) $)^{163}$ \\
\hline earfopnes & ca. 175 occ. (freq. in Ælfric) \\
\hline ge.edcwicod, ge.edcucod & ca. 30 occ. (mainly in Ælfric) ${ }^{164}$ \\
\hline edwist & ca. 40 occ. (freq. in Ælfric) \\
\hline *ge.efenlōecan & ca. 100 occ. (freq. in Ælfric) $)^{165}$ \\
\hline ēhtere & ca. 8o occ. (freq. in Ælfric) \\
\hline ēhtnes & ca. 200 occ. (freq. in Ælfric) \\
\hline elcian, ylcian & ca. 35 occ. (freq. in Ælfric) \\
\hline endelēas & 26 occ. (freq. in Ælfric) \\
\hline endenèxt & ca. 70 occ. (mainly in Ælfric) \\
\hline *+ge.endung & ca. 200 occ. ${ }^{166}$ \\
\hline ēstmete, estmett & 18 occ. (freq. in Ælfric) \\
\hline fēerlìce & ca. 200 occ. (freq. in Ælfric) \\
\hline +ge.fèged & ca. 125 occ. \\
\hline fēowerfeald & 18 occ. (freq. in Ælfric) ${ }^{167}$ \\
\hline$f \bar{d} d a$ & ca. 65 occ. (mainly in Ælfric and in glosses) \\
\hline forgāegednes & 30 occ. (mainly in Ælfric) \\
\hline
\end{tabular}

16o See also the entry in Appendix B, category D.

161 This lemma corresponds to two entries in TOE, diht and ( $g e$ ) diht, but only the first of these has been tagged.

162 This lemma corresponds to two entries in TOE, $d r \bar{y}$ and $d r \bar{y}(l \bar{a} c)$, but only the first of these has been tagged.

163 This lemma corresponds to two entries in TOE, dyrstiglice and (ge)dyrstiglīe, which have both been tagged. The second of these entries subsumes the DOE entries dyrstelice (D) and ge.dyrstelīce (not in appendices).

164 Cf. the $\mathrm{B} 1$ lexeme edcwician, edcucian, and the $\mathrm{C}_{1}$ lexeme ge.edcwician, ge.edcucian.

165 This lemma corresponds to two entries in TOE, geefenlēecan and (ge)efenlēecan, but only the second of these has been tagged. The second of these entries subsumes the $D O E$ entries ge.efenlēecan (D), efenlēecan (not in appendices) and ge.efenlēeht (not in appendices).

166 This lemma corresponds to two entries in TOE, geendung and (ge)endung, which have both been tagged. The second of these entries subsumes the DOE entries ge.endung (D) and endung (not in appendices).

${ }_{167}$ From the citations in the $D O E$ (s.v. feower-feald), it may seem as if there are only four non-Ælfrician texts (I have counted Byrhtferth's Manual and the glosses to the Manual as one text); however, the Lindisfarne Gospels should obviously be seen as distinct from the West-Saxon Gospels, even if they are translations of the same text. 


\begin{tabular}{|c|c|}
\hline *fornēan & ca. 45 occ. (mainly in Ælfric) ${ }^{168}$ \\
\hline *forscyldigian & ca. 40 occ. (mainly in Ælfric) ${ }^{169}$ \\
\hline forsēon & ca. 6 oo occ. (freq. in Ælfric) \\
\hline forwel & ca. 70 occ. (mainly in Ælfric) \\
\hline fracoplice & 11 occ. (freq. in Ælfric) \\
\hline *frcetwung & 24 occ. (freq. in Ælfric) ${ }^{170}$ \\
\hline frēcednes & ca. 110 occ. (freq. in Ælfric) \\
\hline *fremming, fremung & ca. 40 occ. (mainly in Ælfric) $)^{171}$ \\
\hline *frēolsian & 30 occ. (freq. in Ælfric) ${ }^{172}$ \\
\hline frēolstìd & ca. 40 occ. (freq. in Ælfric) \\
\hline füle & 18 occ. (freq. in Ælfric) \\
\hline ge.gada & 20 occ. (freq. in Ælfric) \\
\hline godspellere & ca. 275 occ. (freq. in Ælfric) \\
\hline godspellic & ca. 75 occ. (freq. in Ælfric) \\
\hline hæefenlēas, hafenlēas & 28 occ. (freq. in Ælfric) \\
\hline hæefenleast, hafenleast & 26 occ. (freq. in Ælfric) \\
\hline hēelp & ca. 45 occ. (freq. in Ælfric) \\
\hline häepengyld & ca. 70 occ. (freq. in Ælfric) $)^{173}$ \\
\hline häpenscipe & ca. 8o occ. (freq. in Ælfric) \\
\hline hēafodleahter & ca. 70 occ. (freq. in Ælfric) \\
\hline *hēahge.rēfa & ca. 5 o occ. (freq. in Ælfric) $)^{174}$ \\
\hline heardheortnes & 14 occ. (freq. in Ælfric) \\
\hline hellesūsl & 17 occ. (freq. in Ælfric) $)^{175}$ \\
\hline hellic & ca. $5^{\circ}$ occ. (in prose and glosses, freq. in Ælfric) \\
\hline hēofung & ca. 45 occ. (freq. in Ælfric) \\
\hline
\end{tabular}

168 This lemma could not be found in TOE and has not been tagged.

169 This lemma corresponds to three entries in TOE, forscyldgod, forscyldigan and forscyldigod, all three of which have been tagged.

170 This lemma corresponds to the TOE entry (ge)freetwung, which subsumes two DOE entries: freetwung (D) and ge.frcetwung (not in appendices).

171 This lemma corresponds to two entries in TOE, fremming and fremung, but only the first of these has been tagged.

172 This lemma corresponds to the TOE entry (ge)freolsian, which subsumes three $D O E$ entries: frēolsian (D), ge.frēolsian (not in appendices) and ge.frēolsod (not in appendices).

173 See also the entry in Appendix B, category D.

174 This lemma corresponds to two entries in TOE, hēahgerēfa and hēahgerefa, which have both been tagged.

175 According to the $D O E$ (s.v. helle-sūsl), "[t]he forms may alternatively be taken as two words with helle as gen.sg. of hell." 


$\begin{array}{ll}{ }^{*} \text { hrepian, hreppan } & \text { ca. } 100 \text { occ. (mainly in Ælfric) }{ }^{176} \\ { }^{*} \text { hrȳman } & \text { ca. } 110 \text { occ. (freq. in Ælfric) })^{177} \\ { }^{*} \text { ge.hwēer } & \text { ca. } 110 \text { occ. (freq. in Ælfric) })^{178} \\ { }^{*} \text { ge.hȳrsumian } & \text { ca. } 150 \text { occ. (freq. in Ælfric) }{ }^{179} \\ \text { hysecild } & 17 \text { occ. (freq. in Ælfric) } \\ i & \text { ca. } 55 \text { occ. }(42 \times \text { in ÆGram) }\end{array}$

\section{Appendix B: Ælfrician Vocabulary Found in Prior Scholarship}

This appendix features vocabulary or specific lexical usage that has been noted by previous scholarship to be indicative of the lexical usage of Ælfric of Eynsham. The formatting of the lemmata in this appendix differs somewhat from the formatting used in Appendix A, in that the conventions of the $D O E$ are generally not followed, but rather, the formatting used in the secondary sources. For instance, the spelling of the lemmata in this appendix has directly been taken from the sources (although macrons have been added to indicate long vowels). However, whenever multiple sources are cited that use different spellings for the same lemma (e.g., gecigan/gecȳgan), the $D O E$ is followed. Similarly, while the $D O E$ treats verbs with and without the prefix $g e$ - as two different lemmata, the sources are followed in this appendix: if a source mentions the lemma (ge)gearwian (indicating that it is treating gearwian and gegearwian as a single lemma), then it receives a single entry here. The entries in categories E-G feature translations, which are usually taken directly from the sources that are mentioned in the relevant footnotes (or are translations of these senses, if the sources are written in a language other than English). If a source provides multiple definitions, no more than two are provided in this appendix, but usually only the first definition. Lastly, if a source does not provide a definition for a lemma, the most basic definition is provided

${ }_{176}$ This lemma corresponds to five entries in TOE, hrepian, (ge)hrepian, hrepian/hreppan, (ge)hrepian (ymbe) and (ge)hrepian/hreppan, all five of which have been tagged. The three entries with the optional ge- prefix subsume the DOE entries ge.hrepian, ge.hreppan (A2), hrepian, hreppan (D) and ge.hrepod (not in appendices). For this reason, these three entries have been tagged as D in Evoke. See also the entry in Appendix B, category E1.

177 This lemma corresponds to two entries in TOE, hrieman and (ge)hrieman, but only the first of these has been tagged.

${ }_{17}$ This lemma corresponds to four entries in TOE, gehwēer, (ge)hwēer, elles gehwër and gehwär and pēer, of which only gehwēer and gehwēer and pēer have been tagged.

179 This lemma corresponds to the TOE entry (ge)hiersumian, which subsumes three DOE entries: ge.hȳrsumian (D), hȳrsumian (not in appendices) and ge.hȳrsumod (not in appendices). 
here, based on the consultation of Old English dictionaries. ${ }^{180}$ Information about the frequency of the lemmata in categories A-D is copied from the $D O E$ whenever possible (i.e., for words starting with the letters A-I). Otherwise, this information is taken from the secondary sources or I have counted the occurrences in the DOEC if the secondary sources do not provide any information. Similarly, the categorisation of the lemmata in categories A-D is based on the $D O E$ for lemmata starting with the letters A-I. For words beyond the letter I, the secondary sources or the $D O E C$ are used. Note that some lemmata in Appendix A also appear in Appendix B. For the significance of the asterisks and plus symbols, see the introduction to Appendix A.

\section{Category A: Lemmata That Only Occur in the Works of Elfric}

\section{Subcategory A1: Lemmata with Frequency in $D O E C \geq 5$}

godspell-bodung

7 occ. (in Ælfric) (Timofeeva, 2017: 221) ${ }^{181}$

ofgangende

7 occ. (Williams, 1958: 461; Chapman, 2010: 442$)^{182}$

part

sealmwyrhta

6 occ. (Williams, 1958: 46o; Chapman, 2010:438)

undecliniendlic

22 occ. (Godden, 1980: 213) ${ }^{183}$

underð̄ôdendlic

10 occ. (Williams, 1958: 461; Chapman, 2010: 438)

ungeendigendlic

5 occ. (Williams, 1958: 461; Chapman, 2010: 442)

woruldcempa

6 occ. (Williams, 1958: 461; Chapman, 2010: 442)

5 occ. (Jost, 1950: 139)

\section{Subcategory A2: Lemmata with Frequency in $D O E C<5$}

mistihtendlic

1 occ. (Williams, 1958: 462; Chapman, 2010: 442)

misworoht

1 occ. (Fleming, 2015: 838$)^{185}$

nemniendlic 1 occ. (Williams, 1958: 462; Chapman, 2010: 442)

180 Primarily the DOE, but also Clark Hall's (1960) A Concise Anglo-Saxon Dictionary. Note that this 'primary' sense is not necessarily the sense in which Ælfric most frequently used a lemma. Conversely, the senses given in the literature are not always the first senses recorded by the dictionaries. In any case, Ælfric certainly used lemmata more frequently in particular senses than in others, but as this information would be too time-consuming to record, it has been omitted.

181 According to Timofeeva (2017: 221), this lemma occurs seven times in total in the works of Ælfric. See also the entry in Appendix A, category A1.

182 Chapman (2010: 442) lists this lemma as "ofgangend", but it is found in the works of Ælfric in the nominative singular as "ofgangende", and this is the spelling that is adopted here.

183 According to Godden (1980: 213), this lemma "is not recorded outside Ælfric and may be his own coinage", and it occurs twenty-two times in total in the works of Ælfric.

184 The corresponding entry in TOE has been tagged as A1, based on Jost (1950: 139), who states that this lemma occurs five times in the works of Ælfric. However, I can only find four occurrences in the DOEC.

185 The corresponding entry in TOE is the infinitive, miswyrcan. According to Fleming (2015: 838 ), this lemma occurs once in the works of Ælfric. 


\begin{tabular}{|c|c|}
\hline ofcumende & 1 осc. (Williams, 1958: 461; Chapman, 2010: 443) \\
\hline oferstīgendlic & 3 occ. (Williams, 1958: 462; Chapman, 2010: 442) \\
\hline ofgangendlic & 2 occ. (Williams, 1958: 461; Chapman, 2010: 442) \\
\hline ongēancyrrendlic & 1 occ. (Williams, 1958: 462; Chapman, 2010: 443) \\
\hline onginnendlic & 1 occ. (Chapman, 2010: 442) \\
\hline *rūnung & 4 occ. $(\text { Fleming, } 2015: 838)^{186}$ \\
\hline smēagendlic & 1 occ. (Chapman, 2010: 442) \\
\hline gesprēeelic & 1 occ. $(\text { Chapman, } 2010: 443)^{187}$ \\
\hline sundor-rūnung & 2 occ. (Fleming, 2015: 838) \\
\hline swēgendlic & 1 occ. (Chapman, 2010: 442) \\
\hline swerigendlic & 2 occ. (Williams, 1958: 462; Chapman, 2010: 442) \\
\hline swïgeniht & 1 occ. $\left(\right.$ Hill, 1985: 124) ${ }^{189}$ \\
\hline syndrigendlic & 1 occ. (Williams, 1958: 462; Chapman, 2010: 442) \\
\hline tihtendlic & 4 occ. (Williams, 1958: 462; Chapman, 2010: 442) \\
\hline tōclypigendlic & 1 occ. (Chapman, 2010: 442) \\
\hline tōgeìcendlic & 2 occ. (Williams, 1958: 462; Chapman, 2010: 443) \\
\hline *geðēodendlic & 2 occ. $(\text { Chapman, } 2010: 442)^{190}$ \\
\hline underhlystung & 1 occ. (Chapman, 2010: 442$)$ \\
\hline undertōdāl & 1 occ. (Chapman, 2010: 442) \\
\hline waniendlic & 3 occ. (Williams, 1958: 462; Chapman, 2010: 442) \\
\hline wiðerrōedlic & 1 occ. (Chapman, 2010: 442) \\
\hline wiðmeten $(d)$ lic & 3 occ. $(\text { Williams, 1958: 462; Chapman, 2010: } 442-443)^{191}$ \\
\hline wiðsacendlic & 1 occ. (Williams, 1958: 462; Chapman, 2010: 442) \\
\hline wrēgendlic & 1 occ. (Williams, 1958: 462; Chapman, 2010: 442) \\
\hline wundrigendlic & 1 occ. (Chapman, 2010: 443) \\
\hline
\end{tabular}

186 This lemma corresponds to two entries in TOE, rünung and rüning, which have both been tagged. According to Fleming (2015: 838), this lemma occurs four times in the works of Ælfric.

187 Chapman (2010: 443) lists this lemma as "gesprǣclic", but it is found in Ælfric's Grammar as "gespræecelice", i.e., with a medial $<\mathrm{e}>$, and this is the spelling that is adopted here.

188 According to Fleming (2015: 838), this lemma occurs twice in the works of Ælfric.

189 According to Hill (1985: 124), this lemma occurs only once in the works of Ælfric. See also the related term swigdceg in category B2.

190 This lemma could not be found in $T O E$ and has not been tagged.

191 Chapman (2010: 442-443) seems to consider "wiðmetendlic" and "wiðmetenlic" as two separate lemmata, but seeing as they are both the equivalent of Latin "comparativus", they have been taken as one lemma in this appendix (cf. TOE, which has wipmeten(d)lic). 


\section{Category B: Lemmata That Occur in the Works of Alfric and One Other Text}

\begin{tabular}{|c|c|}
\hline \multicolumn{2}{|c|}{ Subcategory B1: Lemmata with Frequency in $D O E C \geq 5$} \\
\hline alēfian & 25 occ. (mainly in Ælfric) (Jost, 195०: 188 , fn. 5$)^{192}$ \\
\hline +gecyndbōc & 5 occ. (mainly in Aldhelm) (Hawk, 2014: 358) \\
\hline gramlic & ca. 35 occ. (mainly in Ælfric) (Jost, 1950: 121$)^{194}$ \\
\hline lïflēast & 6 occ. $(\text { Shaw, } 2014: 331)^{195}$ \\
\hline gelōmläènde & 6 occ. (Chapman, 2010: 442) \\
\hline stōwlic & 6 occ. (Williams, 1958: 462; Chapman, 2010: 442$)^{196}$ \\
\hline gestrȳnendlic & 5 occ. (Williams, 1958: 462; Chapman, 2010: 442) \\
\hline unlīchamlic & 15 occ. (Williams, 1958: 462; Chapman, 2010: 441) \\
\hline \multicolumn{2}{|c|}{ Subcategory B2: Lemmata with Frequency in $D O E C<5$} \\
\hline +bearnēacninde & 3 occ. $(\text { Treharne, } 2006: 185, \text { n. } 26)^{197}$ \\
\hline *+ēarplcettigen & 2 occ. (Treharne, $2006: 185$, n. 26$)^{198}$ \\
\hline lēerestre & 3 occ. $($ Timofeeva, 2017: 233) \\
\hline *gelōmlāecung & 2 occ. (Not found in sources) ${ }^{200}$ \\
\hline sēðende & 4 occ. (Williams, 1958: 462; Chapman, 2010: 441-442) \\
\hline
\end{tabular}

192 According to Jost (1950: 188, fn. 5), this lexeme almost exclusively occurs in the works of Ælfric. See also the entry in Appendix A, category B1.

193 According to Hawk (2014: 358), the only other occurrences of gecyndbōc are found "in the glosses to Aldhelm's De virginitate III."

194 According to Jost (1950: 121), this lexeme is typical for Ælfric and it is not often found elsewhere. See also gramlice in category $\mathrm{C}_{1}$ in this appendix.

195 If the text De diebus malis was written by Ælfric, as Shaw (2014) argues, this lemma would only occur in the works of Ælfric. However, this text is not mentioned as part of Ælfric's canon in Kleist (2019: 66-206). For this reason, I have not counted De diebus malis as an Ælfrician text, and have placed liffleast in category Bı.

196 Chapman (2010:442) lists this lemma as "stōwelic", but it is found in the works of Ælfric as "stōwlic", i.e., without a medial $<\mathrm{e}\rangle$, and this is the spelling that is adopted here.

197 According to the DOE (s.v. bearn-ēacniende), the only non-Ælfrician occurrence of this lemma is in Ralph d'Escures' homily on the Assumption of the Virgin Mary.

198 See footnote for ge.ēarplcettan (Appendix A, category A2). According to the DOE (s.v. ear-plecttan, éar-plcettian), the only non-Ælfrician occurrence of this lemma is in Ralph d'Escures' homily on the Assumption of the Virgin Mary.

199 According to Timofeeva (2017: 233), this lemma occurs three times in total, twice in the works of Ælfric.

200 This lemma corresponds to two entries for gelomläcing in TOE, one with the sense 'repeated action' and another with the sense 'a multitude, mighty company'. Only the first entry has been tagged. 


\begin{tabular}{|c|c|}
\hline swigdceg & 4 occ. $(\text { Hill, } 1985: 118,123)^{201}$ \\
\hline trūð & 4 occ. $(\text { Breeze, } 1995: 155)^{202}$ \\
\hline twȳnigendlic & 4 occ. (Williams, 1958: 462; Chapman, 2010: 442) \\
\hline ðēodlic & 2 occ. $(\text { Chapman, } 2010: 441)^{203}$ \\
\hline ungebunden & 2 occ. (Williams, 1958: 462; Chapman, 2010: 441) \\
\hline gewīscendlic & 4 occ. (Williams, 1958: 462; Chapman, 2010: 442) \\
\hline gewīscendlīce & 2 occ. (Not found in sources) \\
\hline
\end{tabular}

\section{Category C: Lemmata That Occur in the Works of Elfric and between Two and Four Other Texts}

Subcategory C1: Lemmata with Frequency in $D O E C \geq 5$

+gramlīe

lèdenbōc

lëdensprōec

*stcefcrceft

*ðrōwiendlic

*unefn
8 occ. [in 2 other texts] (Jost, 1950: 121 $)^{204}$

10 occ. [in 4 other texts] (Shaw, 2014: 331)

44 occ. [in 3 other texts] (Chapman, 2010: 440)

8 occ. [in 2 other texts] (Williams, 1958: 461; Chapman, 2010: 440$)^{206}$

25 occ. [in 2 other texts] (Williams, 1958: 462; Chapman, 2010: 441$)^{207}$

9 occ. [in 4 other texts] (Chapman, 2010: 441$)^{208}$

201 The corresponding entry in TOE is the plural, swigdagas. According to Hill (1985: 123), three out of four total occurrences of this lemma are found in the works of Ælfric, with the remaining instance found in a translation of the Regularis concordia. See also the related term swigeniht in category A2.

202 According to Breeze (1995: 155), the other text in which this lemma occurs is a "late glossary".

203 Chapman (2010: 441) lists this lemma as "ðeodlic nama", but seeing as it corresponds to Latin "gentile (nomen)", the second element, "nama", should have been placed in brackets (and it has, therefore, not been given here).

204 According to Jost (1950: 121), this lexeme is typical for Ælfric and it is not often found elsewhere. See also gramlic in category B1 in this appendix.

205 If the text De diebus malis was written by Ælfric, as Shaw (2014) argues, this lemma would occur in only three non-Ælfrician texts. However, this text is not mentioned as part of Ælfric's canon in Kleist (2019: 66-206). For this reason, I have not counted De diebus malis as an Ælfrician text, and have counted four non-Ælfrician texts for lēdenbōc. Shaw (2014: 331) states that, aside from its occurrences in De diebus malis, six out of the nine remaining instances of this lemma are found in the works of Ælfric.

206 This lemma corresponds to two entries in TOE, stcefcrceft and stcefcrceftas, but only the first of these has been tagged.

207 This lemma corresponds to three entries in TOE, prōwendlic, prōwiendlic and prōwendlic dea $a p$, of which only the first two have been tagged.

208 This lemma corresponds to two entries in TOE, unefn and unefen, but only the first of these has been tagged. 
unfulfremed

5 occ. [in 3 other texts] (Williams, 1958: 462; Chapman, 2010: 442 )

ungebigendlic 6 occ. [in 2 other texts] (Williams, 1958: 461; Chapman, 2010: 441)

\section{Subcategory C2: Lemmata with Frequency in $D O E C<5$}

None

\section{Category D: Widely Used Lemmata, Found in Five or More Other Texts, Frequently Found in the Works of Alfric}

ānrāe de

deriendlic

* + gedwola

* +gedwolman

+ gōdnyss

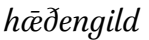

orðung

stcefgefēg

*getācnung

*geð̄odnys

wìflic ca. 100 occ. (freq. in Ælfric) (Shaw, 2014: 331, fn. 29) 209

ca. 6 o occ. (esp. freq. in Ælfric $\left[25^{\times}\right]$and HyGl $[18 \times]$ )

(Shaw, 2014: 331 $)^{210}$

ca. 140 occ. (Jost, 1950: $25^{2}$, fn. 1$)^{211}$

ca. 5 o occ. (Jost, 1950: 252, fn. 1$)^{212}$

ca. 25 o occ. (Jost, 1950: 123 and fn. 2$)^{213}$

ca. 70 occ. (freq. in Ælfric) (Jost, 1950: 131) ${ }^{214}$

16 occ. (Chapman, 2010: 440)

33 occ. (Williams, 1958: 461; Chapman, 2010: 440)

208 occ. (Williams, 1958: 461; Chapman, 2010: 440) ${ }^{215}$

5o occ. (Williams, 1958: 461; Chapman, 2010: 440)216

27 occ. (Williams, 1958: 462; Chapman, 2010: 441)

209 See also the entry in Appendix A, category D.

210 See also the entry in Appendix A, category D.

211 This lemma corresponds to three entries in TOE: two entries for gedwola, and one for (ge)dwola. Only one gedwola entry and (ge)dwola have been tagged, since gedwola with the sense 'a madman' is not attested in the works of Ælfric. The entry ( $g e) d$ wola subsumes the $D O E$ entries ge.dwola (D) and dwola (not in appendices). According to Jost (1950: 252, fn. 1), gedwola and gedwolman are common in the works of Ælfric.

212 This lemma corresponds to two entries in TOE, (ge)dwolmann and gedwolmann, which have both been tagged. The first of these entries subsumes the DOE entries dwolmann (A2) and ge.dwolmann (Appendix B, category D). For this reason, this entry has been tagged as D in Evoke. See also the previous footnote.

213 See also Jost (1950: 137). According to Jost (1950: 123 and fn. 2), this lexeme, which is used of God and good people, is very common in the works of Ælfric.

214 According to Jost (1950: 131), this lexeme is almost exclusively found in the works of Ælfric. See also the entry in Appendix A, category D.

215 This lemma corresponds to two entries in TOE, getācnung and (ge)tācnung, which have both been tagged. The second of these entries subsumes the lemmata ge.tācnung $(\mathrm{D})$ and tācnung (not in appendices).

216 This lemma corresponds to three entries in TOE, gepēodnes, (ge)pēodnes and lichamlice gepēodnes, of which only the first has been tagged. 


\section{Category E: Alfric Has a Relative Preference for Particular Lemmata over Synonymous Lemmata}

Subcategory E1: Preferences Are, Overall, Unrelated to Specific

Semantic or Contextual Usages

$\bar{a} g a n$

andwyrdan

$\bar{e} l c / g e h w \bar{a} / g e h w i l c$

celfremed/celpēodig

bōcere

burh

cennan/acennan

cweartern

gedyrstlēean

èadig

forhogian 'to have, possess'

'to answer'

'every'

'foreign'

'scribe, writer'

'city'

'to bear a child'

'prison'

'to dare'

'blessed'

'to despise' preferred to geāgnian ${ }^{217}$

preferred to andswarian ${ }^{218}$

preferred to $\bar{x}$ ghwilc ${ }^{219}$

preferred to fremde 220

preferred to writere 221

preferred to ceaster/port ${ }^{222}$

preferred to geberan ${ }^{223}$

preferred to carcern $^{224}$

preferred to (ge)prīstlēecan 225

preferred to gescēligig

preferred to forhycgan ${ }^{227}$

217 Ono (1998: 304); Ono (1998: 304) indicates that, in the works of Ælfric, ägan occurs 38 times and geāgnian occurs 24 times. These numbers include derived forms such as 'geagniendlice' (Ono, 1998: 302-303). See also geāgnian in category F.

218 Jost (1927: 184); reiterated by Magennis (1986: 325); Takeuchi (1998: 342). According to Takeuchi (1998: 342), andswarian occurs only 30 times in the works of Ælfric, while andwyrdan occurs 374 times. See also the entry in Appendix A, category D.

219 Jost (1950: 162-166); reiterated by Pope (1967: 100). According to Jost (1950: 162-166), the first lemma, $\bar{e} l c$, is used most frequently by Ælfric; he also mentions that there are only three occurrences of $\bar{x}$ ghwilc in the works of Ælfric; see also Jost (1950: 162-166) for more detailed information on the usage of these lemmata.

220 Pope (1967: 99); citing Dietrich (1855: 544-545, fn. 140); reiterated (but only mentioning celpēodig) by Magennis (1986: 325). According to Hofstetter (1987: 38), celfremed (and the related adjective gecelfremod, also used by Ælfric) is part of the Winchester vocabulary. Pope (1967: 99-10o, fn. 3) and Hofstetter $(1987: 38)$ both mention that Ælfric uses fremde only once.

221 Fleming (2015: 834).

222 Jost (1927: 185); reiterated by Magennis (1986: 325). According to Jost (1927: 185), Ælfric uses ceaster much less frequently than burh, and uses port only a handful of times.

223 Jost (1950: 122, fn. 4); according to Jost (1950: 122, fn. 4), geberan is not infrequent in the works of Ælfric.

224 Pope (1967: 99-100); citing Dietrich (1855: 544-545, fn. 140). According to Dietrich (1855: $544-545$, fn. 140), Ælfric only uses cweartern.

225 According to Hofstetter (1987: 38), gedyrstlēecan is part of the Winchester vocabulary; Ælfric never uses (ge)pristlēecan (44).

226 Jost (1950: 123).

227 Jost (1950: 174); reiterated by Pope (1967: 100). According to Jost (1950: 174, fn. 3), the single occurrence of the form 'forhygedon' in the first series of Catholic Homilies probably shows scribal influence. Cf. hogian in this category. 


\begin{tabular}{|c|c|c|}
\hline gefrēdan & 'to feel' & preferred to $f e \overline{l a n} n^{228}$ \\
\hline gegaderian & 'to gather' & preferred to gesamnian 229 \\
\hline (ge)gearcian & 'to prepare' & preferred to $(g e)$ gearwian ${ }^{230}$ \\
\hline hātan/gecīgan & 'to call' & $\begin{array}{l}\text { preferred to (ge)namian/ } \\
\text { (ge)nemnan }\end{array}$ \\
\hline hogian & $\begin{array}{l}\text { 'to think; to be } \\
\text { concerned about' }\end{array}$ & preferred to hycgan ${ }^{232}$ \\
\hline hreppan/(ge)hrepian & 'to touch' & $\begin{array}{l}\text { preferred to onhrinan/ } \\
\text { cethrinan }^{233}\end{array}$ \\
\hline mōdig- & $\begin{array}{l}\text { lemmata } \\
\text { relating to 'pride' }\end{array}$ & $\begin{array}{l}\text { preferred to } \\
\text { ofermōd-/prūt-/oferhygd-234 }\end{array}$ \\
\hline
\end{tabular}

228 Pope (1967: 99); citing Dietrich (1855:544-545, fn. 140). Klein (2012: 493) argues that frēdan (and related forms) is part of the Winchester vocabulary, although it also appears in early West Saxon; he also notes that Ælfric never uses félan or related forms (491).

229 Jost (1950: 137, fn. 7).

230 Jost (1950: 156, 174); reiterated by Pope (1967: 99); reiterated by Magennis (1986: 325); first mentioned by Dietrich (1855: 544-545, fn. 140). Both Dietrich (1855:544-545, fn. 140) and Jost (1950: 174) mention that Ælfric never uses gearwian. According to Hofstetter (1987: 38), (ge)gearcian and the related noun gearcung (which Ælfric also uses) are part of the Winchester vocabulary, and he also confirms that Ælfric never uses (ge)gearwian.

231 Jost (1927: 184); reiterated by Magennis (1986: 325). According to Jost (1927: 184), Ælfric uses genamian and (ge)nemnan only occasionally. According to Godden (1980: 213), the verb gecigan is used much less frequently by Ælfric in the later part of his career.

232 Jost (1950: 174); reiterated by Pope (1967: 10o); first mentioned by Dietrich (1855: 544-545, fn. 140). Jost (1950: 174, fn. 3) points out that hycgan is occasionally used by Ælfric, but in quite a different sense, namely, 'to endeavour; to make an effort'. Cf. forhogian in this category.

233 Pope (1967: 99); citing Dietrich (1855:544-545, fn. 140); Jost (1927: 202) (who mentions the optional ge-prefix before hrepian and the verb cethrinan); reiterated by Magennis (1986: 325). Klein (2012: 485) argues that hrepian (and related forms) is part of the Winchester vocabulary; he also notes that Ælfric never uses hrinan or related forms (484). See also the entries in Appendix A, category A2 (forms with the ge-prefix) and category D (unprefixed forms).

234 Schabram (1965: 92). Schabram (1965: 92) mentions that the works of Ælfric feature 124 occurrences of lemmata based on mōdig-: mōdigness 'pride', mōdig 'proud', mōdiglīce 'proudly', mōdigian 'to be/become proud', against three instances of lemmata based on ofermōd- (ofermēttu and ofermōd, both meaning 'pride'), one instance of prȳte 'pride' and one instance of oferhygdig 'proud'. According to Hofstetter (1987: 38), the mōdig- lexical family is part of the Winchester vocabulary; in addition, he argues that the one instance of pryte in the works of Ælfric is semantically distinct from the other lemmata, because Ælfric apparently uses it to translate arrogantia 'arrogance', not superbia 'pride' (54). 


\begin{tabular}{|c|c|c|}
\hline$n \bar{a} n$ & 'no, none' & preferred to $n \bar{e} n i g^{235}$ \\
\hline ordfruma & 'beginning' & preferred to fruma ${ }^{236}$ \\
\hline gereord & 'language' & preferred to gepèode/lāeden 237 \\
\hline sundorhālga & 'Pharisee' & preferred to phariseus/fariseisc $^{238}$ \\
\hline tācn & ‘sign’ & preferred to mircels 239 \\
\hline tōbrȳtan/tōcwȳsan & 'to crush, destroy' & preferred to forprōstan ${ }^{240}$ \\
\hline understandan & 'to understand' & $\begin{array}{l}\text { preferred to undergytan/ } \\
\text { ongytan }^{241}\end{array}$ \\
\hline yrðling & 'farmer' & preferred to tilia/eorðtilia ${ }^{242}$ \\
\hline
\end{tabular}

235 Jost (1950: 16o-161); Pope (1967: 10o); reiterated by Magennis (1986: 325). According to the sources that Jost (1950: 16o, fn. 1) mentions, Ælfric never uses nēnig. Jost (1950: 161) and Pope (1967:100) both note that this seems to have been a more general preference of West Saxon.

236 Sato (2011: 308); according to Sato (2011: 308), who cites the DOE (s.v. fruma, sense 1.c), Ælfric "uses fruma exclusively in the phrase cet fruman 'at first' and never uses it on its own." Note, however, that a search for 'angin' in the DOEC shows that anginn is used much more frequently by Ælfric for 'beginning' than ordfruma.

237 Jost (1927: 185); according to Jost (1927: 185), gepéode does not occur infrequently in the works of Ælfric, and lēelen is only used in the sense of 'Latin' rather than 'language'. See also Jost (1950: 181).

238 Fleming (2015: 836, 839-841). According to Fleming (2015: 836), "[sundorhālga] occurs at least thirty-five times in [Ælfric's] writings, whereas there are only four or five occurrences of the loanwords."

239 Jost (1927: 194); according to Jost (1927: 194), Ælfric uses mircels with the meaning 'sign' only once, in his Lives of Saints.

240 Hofstetter (1987:38). According to Hofstetter (1987:38), the verbs tōbrȳtan and tōcwȳsan are both part of the Winchester vocabulary, and they are used about equally as often by Ælfric. He also notes that Ælfric uses forprēestan only once.

241 Ono (1988: 84-85); Ono (1988: 84-85) mentions that in Ælfric's Catholic Homilies, Lives of Saints, and the homilies edited by Pope, understandan occurs 112 times, undergytan occurs 40 times, and ongytan occurs 15 times. Ono (1986: 571 ) notes that $39 \%$ of occurrences of undergytan in the Old English corpus can be found in the works of Ælfric; in addition, Ono (1986: 572) adduces the numerous occurrences of this verb in texts associated with the Winchester vocabulary to argue that undergytan is a Winchester lexeme.

242 Jost (1927: 185); according to Jost (1927: 185), Ælfric never uses eorðtilia. 


\section{Subcategory E2: Preferences Are, Overall, Related to Specific} Semantic or Contextual Usages, or Other Factors

ege

gēar

gelapung

miht

(ge)rihtlēecan

snotor(ness) 'fear'

'year'

'church'

'power'

'to correct'

'prudent'

'prudence' preferred to $\overline{o g a}$ (when "refer

[ring] to the fear of the Lord") ${ }^{243}$

preferred to winter (when indi-

cating ages $)^{244}$

preferred to cirice (in senses

relating to communities of

Christian believers, e.g., 'the

universal church' $)^{245}$

preferred to maegen (for the trans-

lation of Latin virtūs in senses

relating to 'power', not 'virtue') ${ }^{246}$

preferred to $(g e)$ rihtan (in

figurative senses) $)^{247}$

preferred to wcer(scipe)/

glēaw(ness)/snyttru (when rendering Latin prūdēns/prüdentia) ${ }^{248}$

243 Gretsch (2001: 59-6o); ōga is used "in a general sense" (Gretsch, 2001: 59). According to Gretsch (2001: 59-6o), this particular usage is part of the Winchester vocabulary, and $\bar{o} g a$ is a "Winchester word". She notes that Ælfric adheres to this semantic differentiation quite consistently: "The vast majority of the seventy-one occurrences of ege in his works (almost four fifths) refer to the fear of the Lord, whereas God is referred to only once among the thirty-seven occurrences of oga" (Gretsch, 2001: 6o). See also Hofstetter (1987: $38,49-50)$.

244 Jost (1927: 188).

245 Hofstetter $\left(1987: 9^{-11}, 38\right)$. According to Hofstetter (1987: 9-11, 38), this particular usage is part of the Winchester vocabulary. Hofstetter $(1987: 38)$ indicates that, in senses relating to communities of Christian believers, Ælfric uses cirice only 3 times, and gelapung 223 times; for the discussion of other possible examples of non-Winchester usage of cirice in the works of Ælfric, see Hofstetter (1987: 44-48).

246 Hofstetter (1987: 12-13, 38, 48-49). According to Hofstetter (1987: 12-13, 38, 48-49), this particular usage is part of the Winchester vocabulary. Hofstetter $(1987: 38)$ indicates that, when translating Latin virtūs in senses relating to 'power', Ælfric uses maegen only twice, and miht 94 times. In the sense of 'virtue', Ælfric uses miht and mogen almost equally as often: 38 and 40 times, respectively.

247 Hofstetter (1987:51); conversely, ( $g$ e)rihtan is primarily (but not exclusively) used in literal senses. While the verb (ge)rihtlēecan is part of the Winchester vocabulary according to Hofstetter (1987: 38), it would seem that the difference in usage between (ge)rihtlēean and (ge)rihtan is particular to Ælfric (51). Jost (1950: 137-138) labels gerihtlēecan as an 'Ælfricwort'.

248 Seebold (1974: $311,33^{2-333)}$ ). According to Seebold (1974: 324$)$, this preference is characteristic for the so-called "Benediktiner-Gruppe"; Ono (1988: 83) states that "the Benedictine group $[. .$.$] includes the Winchester group".$ 
wīs $\quad$ 'wise'/'wisdom'

wuldorbēag 'crown' preferred to snotor/snyttru

(when rendering Latin sapiēns)

sapientia $)^{249}$

preferred to cynehelm (in a

figurative and Christian sense $)^{250}$

\section{Category F: IElfric Has a Relative Preference for Specific Morphological Forms}

\begin{tabular}{|c|c|c|}
\hline geāgnian & 'to have, possess' & preferred to āgnian $^{251}$ \\
\hline cetforan & 'before' & preferred to beforan/tōforan ${ }^{252}$ \\
\hline bebod & 'command' & preferred to gebod $^{253}$ \\
\hline behrēowsian/ & 'to repent'/ & $\begin{array}{l}\text { preferred to hrēowsian/ } \\
\text { hrēowsung }^{254}\end{array}$ \\
\hline behrēowsung & 'repentance' & \\
\hline
\end{tabular}

249 Seebold (1974: 311, 332); according to Seebold (1974: 321), this preference is characteristic of 'southern English' in general. Seebold (1974: 311, 313) notes that Ælfric does use snotor as an epithet for King Solomon. Interestingly, Ælfric renders insipiēns as both unwīs and unsnotor, using the former somewhat more often than the latter (Seebold, 1974: 313).

$25^{\circ}$ Hofstetter $(1987: 17-18,38,56)$, citing (on p. 56) J. Kirschner, Die Bezeichnungen für Kranz und Krone im Altenglischen (Munich: Salzer, 1975), p. 216. According to Hofstetter (1987: $17-18,38,56)$, wuldorbēag and the related verb wuldorbēagian are part of the Winchester vocabulary, and, considering the fact that the use of cynehelm in a figurative sense is avoided in Winchester texts, the semantic differentiation is also characteristic of this vocabulary. Hofstetter (1987: 38) indicates that, in a figurative and religious sense, Ælfric uses cynehelm only 3 times, and wuldorbēag (including related lemmata) 15 times. Hofstetter $(1987: 56-57)$ provides arguments for not counting as such a number of figurative instances of cynehelm that are mentioned by Kirschner, which makes the semantic differentiation between wuldorbēag and cynehelm even more salient. In other words, cynehelm is used in the works of Ælfric primarily to refer to a literal 'crown'.

251 Ono (1998: 304); Ono (1998: 304) indicates that, in the works of Ælfric, geägnian occurs 24 times and agnian occurs only once. These numbers include derived forms such as 'geagniendlice' and, as the only instance of ägnian, the agentive noun 'agnigend', which translates Latin 'possessorem' in Genesis 14:23; furthermore, two past participles have been counted as instances of geāgnian (Ono, 1998: 302-304). According to Ono (1998: 304), the preference of geāgnian to unprefixed àgnian seems to be typical of Winchester usage. See also āgan in category E1.

$25^{2}$ Jost (1927: 185); reiterated by Magennis (1986: 325) (who adds the form töforan). See also the entry in Appendix A, category D.

253 Sato (2011: 308); according to Sato (2011: 308), there are no instances of gebod in both series of Ælfric's Catholic Homilies and in his Lives of Saints.

254 Jost (1950: 176); Hofstetter (1987: 38, 53). Both Jost (1950: 176) and Hofstetter $(1987: 38,53)$ mention that Ælfric never uses the unprefixed forms. According to Hofstetter (1987: 38, 53), this particular preference is part of the Winchester vocabulary. 


\begin{tabular}{|c|c|c|}
\hline forgyfan & 'to give' & preferred to agyfan/gyfan 255 \\
\hline forgieldan & 'to reward' & preferred to gieldan ${ }^{256}$ \\
\hline forwiernan & 'to prevent' & preferred to wiernan ${ }^{257}$ \\
\hline libban & 'to live' & preferred to gelibban ${ }^{258}$ \\
\hline oncnāwan & 'to recognise' & $\begin{array}{l}\text { preferred to tōcnāwan/ } \\
\text { gecnāwan }^{259}\end{array}$ \\
\hline sellan & 'to give' & preferred to gesellan ${ }^{260}$ \\
\hline underfōn & 'to receive' & preferred to onfō $n^{261}$ \\
\hline untrum & 'weak, sick' & preferred to mettrum ${ }^{262}$ \\
\hline
\end{tabular}

255 Takeuchi (1998: 342); Takeuchi (1998: 342) indicates that, in the works of Ælfric, forgyfan occurs 361 times, agyfan occurs $5^{2}$ times, and gyfan occurs 18 times. Takeuchi (1998: 348) notes that these verbs are not entirely semantically equivalent: 12 out of the $5^{2}$ instances of agyfan in the works of Ælfric are part of the collocation gäst agyfan 'to die', and, moreover, Ælfric "does not use [agyfan] in the sense in which sellan or forgyfan is used." Concerning gyfan, Takeuchi (1998: 346) states that "[i]n Ælfric, gyfan occurs in contexts where some supernatural being, like God or Christ, for instance, bestows something on someone." See also Sato (2011: 308), who states that there are only four instances of gyfan in both series of Ælfric's Catholic Homilies and in his Lives of Saints. See also forgyfan in category G.

256 Sato (2011: 308); according to Sato (2011: 308), there are no instances of gieldan in both series of Ælfric's Catholic Homilies and in his Lives of Saints.

257 Sato (2011: 308); according to Sato (2011: 308), there are no instances of wiernan in both series of Ælfric's Catholic Homilies and in his Lives of Saints.

258 Jost (1950: 135, fn. 2); according to Jost (1950: 135, fn. 2), Ælfric never uses gelibban, and Jost mentions that this verb generally means 'to experience', except in the Lindisfarne Gospels.

259 Jost (1950: 137, fn. 4); Ono (1988: 85). According to Jost (1950: 137, fn. 4), gecnāwan is used much more rarely by Ælfric than tōcnāwan; Ono (1988: 85) mentions that in Ælfric's Catholic Homilies, Lives of Saints, and the homilies edited by Pope, oncnāwan occurs 170 times, tōcnāwan occurs 71 times, and gecnāwan occurs 12 times. Jost (1950: 131) also notes that tōcnāwan is rarely found outside of the works of Ælfric.

26o Takeuchi (1998: 342); Takeuchi (1998: 342) indicates that, in the works of Ælfric, sellan occurs 370 times and gesellan occurs 34 times. Takeuchi (1998:345) notes that these verbs are not entirely semantically equivalent: in general, gesellan seems to be used primarily "with concrete objects, material and animate", and it is also found in the works of Ælfric with the meaning 'to sell'. Conversely, sellan takes "almost any kind of accusative object" (Takeuchi, 1998: 343).

261 Jost (1927: 184); according to Jost (1927: 184), Ælfric uses onfōn much less frequently.

262 Pope (1967: 100); citing Dietrich (1855:544-545, fn. 140). Pope (1967: 100, fn. 4) mentions that Bosworth-Toller contains one Ælfrician quotation featuring mettrum (in the Catholic Homilies). The lemmata untrum and mettrum are given as examples of the more general observation, made by Dietrich (1855: 544-545, fn. 140) and reiterated by Pope (1967: 100), that Ælfric avoids using the prefix med-. 


\section{Category G: Widely Used Lemmata, But Alfric Uses Them in a Specific Context or Meaning}

Bestandan in the sense of 'to bury' is primarily found in the works of Ælfric (Jost, 1950: 144).

Forgyfan is often used with the sense of 'to give' (Jost, 1950: 120; Takeuchi, 1998: $349-351){ }^{263}$

The regular present participle of the verb libban 'to live', used by Ælfric, is 'libbende', while the alternative form "lifi $(g)$ ende $[. .$.$] is used by Ælfric exclusively as an honorific$ adjective applied to the divinity or to some pretender to divinity" (Pope, 1967: 100).

\section{Category H: Other (Lemmata That Do Not Fit into the Categories Above)}

faran is a composite verb in the works of Ælfric: "Ælfric uses faran in the present and in the past participle, ferran in the preterite, thus making a single verb" (Pope, 1967:101). mycclum is commonly used by Ælfric to intensify verbs (Jost, 1950: 137, fn. 6).

ormēte is a favourite of Ælfric's (Jost, 1950: $137, \mathrm{fn} .2) .^{264}$

onbryrdan is typical for Ælfric (Jost, 1950: 137, fn. 5).

pwȳrlic can mostly be found in the works of Ælfric (Jost, 1950: 130).

wiðmeten is "relatively rare" and Ælfrician (Treharne, 2006: 185, n. 26).

263 Takeuchi (1998: 349-351) notes that Ælfric uses forgyfan in the senses of 'to forgive' and 'to give', but that the former sense becomes much less frequent in Ælfric's later works; the table on p. 35 o shows that there is a distinct drop in occurrences with the meaning to forgive' after the first series of Catholic Homilies.

264 See also Jost (1950: 145 and, on that page, fn. 1). 